\title{
Seasonal variability of atmospheric nitrogen oxides and non-methane hydrocarbons at the GEOSummit station, Greenland
}

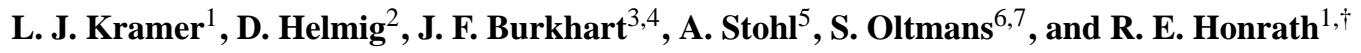 \\ ${ }^{1}$ Atmospheric Sciences Program/Dept. of Geological and Mining Engineering and Sciences, Michigan Technological \\ University, Houghton, Michigan, USA \\ ${ }^{2}$ Institute of Arctic and Alpine Research, University of Colorado, Boulder, Colorado, USA \\ ${ }^{3}$ Department of Geosciences, University of Oslo, Oslo, Norway \\ ${ }^{4}$ Sierra Nevada Research Institute, University of California, Merced, California, USA \\ ${ }^{5}$ Norwegian Institute for Air Research (NILU), Kjeller, Norway \\ ${ }^{6}$ NOAA Earth System Research Laboratory, Boulder, Colorado, USA \\ ${ }^{7}$ CIRES, University of Colorado, Boulder, Colorado, USA \\ $\dagger$ deceased
}

Correspondence to: L. J. Kramer (lkramer@mtu.edu)

Received: 01 May 2014 - Published in Atmos. Chem. Phys. Discuss.: 27 May 2014

Revised: 30 April 2015 - Accepted: 07 May 2015 - Published: 22 June 2015

\begin{abstract}
Measurements of atmospheric nitrogen oxides $\mathrm{NO}_{x} \quad\left(\mathrm{NO}_{x}=\mathrm{NO}+\mathrm{NO}_{2}\right)$, peroxyacetyl nitrate (PAN), $\mathrm{NO}_{y}$, and non-methane hydrocarbons (NMHC) were taken at the Greenland Environmental Observatory at Summit (GEOSummit) station, Greenland $\left(72.34^{\circ} \mathrm{N}, 38.29^{\circ} \mathrm{W}\right.$; 3212 m a.s.1.), from July 2008 to July 2010. The data set represents the first year-round concurrent record of these compounds sampled at a high latitude Arctic site. Here, the study focused on the seasonal variability of these important ozone $\left(\mathrm{O}_{3}\right)$ precursors in the Arctic troposphere and the impact from transported anthropogenic and biomass burning emissions. Our analysis shows that PAN is the dominant $\mathrm{NO}_{y}$ species in all seasons at Summit, varying from 42 to $76 \%$; however, we find that odd $\mathrm{NO}_{y}$ species (odd $\mathrm{NO}_{y}=\mathrm{NO}_{y}-\mathrm{PAN}-\mathrm{NO}_{x}$ ) contribute a large amount to the total $\mathrm{NO}_{y}$ speciation. We hypothesize that the source of this odd $\mathrm{NO}_{y}$ is most likely alkyl nitrates and nitric acid $\left(\mathrm{HNO}_{3}\right)$ from transported pollution, and photochemically produced species such as nitrous acid (HONO).

FLEXPART retroplume analyses and black carbon (BC) tracers for anthropogenic and biomass burning (BB) emissions were used to identify periods when the site was impacted by polluted air masses. Europe contributed the largest source of anthropogenic emissions during the winter months (November-March) with $56 \%$ of the total anthropogenic BC
\end{abstract}

tracer originating from Europe in 2008-2009 and $69 \%$ in 2009-2010. The polluted plumes resulted in mean enhancements above background levels up to $334,295,88$, and $1119 \mathrm{pmol} \mathrm{mol}^{-1}$ for $\mathrm{NO}_{y}, \mathrm{PAN}, \mathrm{NO}_{x}$, and ethane, respectively, over the two winters. Enhancements in $\mathrm{O}_{3}$ precursors during the second winter were typically higher, which may be attributed to the increase in European polluted air masses transported to Summit in 2009-2010 compared to 2008-2009. $\mathrm{O}_{3}$ levels were highly variable within the sampled anthropogenic plumes with mean $\Delta \mathrm{O}_{3}$ levels ranging from -6.7 to $7.6 \mathrm{nmol} \mathrm{mol}^{-1}$ during the winter periods.

North America was the primary source of biomass burning emissions during the summer; however, only 13 BB events were observed as the number of air masses transported to Summit, with significant BB emissions, was low in general during the measurement period. The BB plumes were typically very aged, with median transport times to the site from the source region of 14 days. The analyses of $\mathrm{O}_{3}$ and precursor levels during the $\mathrm{BB}$ events indicate that some of the plumes sampled impacted the atmospheric chemistry at Summit, with enhancements observed in all measured species. 


\section{Introduction}

The seasonality of ozone $\left(\mathrm{O}_{3}\right)$ and its precursors for photochemical production, such as nitrogen oxides, i.e. $\mathrm{NO}_{x}$ $\left(\mathrm{NO}_{x}=\mathrm{NO}+\mathrm{NO}_{2}\right)$, peroxyacetyl nitrate $(\mathrm{PAN})$, and nonmethane hydrocarbons (NMHC), in the remote Arctic troposphere is governed by a combination of transport pathways, photochemistry, and stratospheric influx (Klonecki et al., 2003; Stohl et al., 2006; Law and Stohl, 2007; Liang et al., 2011). Improving our knowledge on the seasonality of $\mathrm{O}_{3}$ and its precursors and the relative importance of source regions and transport variability is essential as recent studies have suggested that tropospheric $\mathrm{O}_{3}$ may have a large impact on radiative forcing and climate feedbacks in the Arctic region (Shindell et al., 2006; Shindell, 2007; Quinn et al., 2008).

Polluted air masses originating from anthropogenic and biomass burning sources in the mid-latitude regions can transport long-lived reservoir species of $\mathrm{NO}_{x}$, such as PAN, and nitric acid $\left(\mathrm{HNO}_{3}\right)$, to the Arctic region (Wofsy et al., 1992; Wespes et al., 2012), which may reform $\mathrm{NO}_{x}$ and result in enhanced levels far downwind from the emission sources (Beine et al., 1997; Walker et al., 2010). NMHC may also be transported in air masses from anthropogenic and biomass burning sources. The mole fractions of NMHC in the Arctic atmosphere can vary greatly during the year due to seasonal variability in emissions, transport pathway variability, and the reaction with OH radicals (Jobson et al., 1994; Blake et al., 2003; Swanson et al., 2003).

Studies of pollution plumes with airborne, satellite- and ground-based observations, and model simulations show that long-range transport from Europe and North America to the lower Arctic troposphere may constitute a large source of tropospheric $\mathrm{O}_{3}$ and $\mathrm{O}_{3}$ precursors, whereas at higher altitude, pollution plumes transported from Asia are an important source (e.g. Atlas et al., 2003; Klonecki et al., 2003; Lamarque and Hess, 2003; Law and Stohl, 2007; Shindell et al., 2008; Fisher et al., 2010; Singh et al., 2010; Walker et al., 2012; Wespes et al., 2012; Bian et al., 2013). A large contribution to the seasonality of $\mathrm{O}_{3}$ and $\mathrm{O}_{3}$ precursors in the Arctic troposphere is due to variability in the location of the Arctic polar front (Klonecki et al., 2003; Stohl, 2006). During winter in the Northern Hemisphere, the polar front expands southward over North America, Europe, and Siberia allowing for direct transport of polluted air masses from sources within these latitudes to the Arctic. The Arctic polar front recedes in summer, reducing the impact of these pollution sources on the Arctic lower troposphere. However, it has been shown that the transport of emissions from biomass burning regions to the Arctic is possible during summer (Stohl, 2006) and that they can strongly impact the atmosphere above GEOSummit station (Stohl et al., 2006). Results from a modelling study by Walker et al. (2012) using tagged emissions in the global chemical transport model GEOS-Chem show that during summer the primary emis- sions that impact the production of $\mathrm{O}_{3}$ in the Arctic region were from high latitude regions, whereas, during the fall and winter periods, transport of emissions from mid-latitude regions in North America and Europe is possible.

A number of studies have discussed the seasonality of surface $\mathrm{O}_{3}$ (Bottenheim et al., 1994; Beine et al., 1997; Monks, 2000; Browell et al., 2003; Helmig et al., 2007b; Walker et al., 2012), nitrogen oxides (Barrie and Bottenheim, 1991; Honrath and Jaffe, 1992; Bottenheim et al., 1994; Muthuramu et al., 1994; Beine et al., 1997; Solberg et al., 1997; Dibb et al., 1998; Munger et al., 1999; Beine and Krognes, 2000; Stroud et al., 2003; Thomas et al., 2011), and NMHC (Jobson et al., 1994; Blake et al., 2003; Klonecki et al., 2003; Swanson et al., 2003; Helmig et al., 2014) in the Arctic. However, due to the logistical difficulties in measuring at remote Arctic locations, the majority of seasonal studies have taken place at coastal sites in northern Europe, Canada, and Alaska, or focused on the late spring/summer periods. Seasonal and interannual studies of nitrogen oxides in the remote Arctic troposphere are largely missing. The high latitude Arctic has negligible impact from local pollution sources, and local production of $\mathrm{NO}_{x}$ from PAN decomposition is expected to be small in this cold region. Therefore, enhanced mole fractions of nitrogen oxides are primarily a result of long-range transported pollution from anthropogenic or biomass burning sources in Europe, North America, and Asia, or of downward transport from the stratosphere (e.g. Liang et al., 2011). Measurements within the boundary layer over Greenland ice sheet are also influenced by emissions from photochemical reactions within the snowpack (Grannas et al., 2007, and references therein), and variability in the boundary layer height (Cohen et al., 2007; Anderson and Neff, 2008; Van Dam et al., 2013), both of which may impact the observed $\mathrm{NO}_{y}$ budget and seasonal cycle of $\mathrm{O}_{3}$ precursors in this region.

A build-up of $\mathrm{O}_{3}$ precursors during winter in the Arctic free troposphere may have important implications for the tropospheric $\mathrm{O}_{3}$ budget in the mid-latitudes during late spring and early summer (Gilman et al., 2010). Modelling studies have postulated that air masses originating from the Arctic region can result in the transport of $\mathrm{NO}_{y}$ and $\mathrm{NMHC}$ to the North Atlantic and enhance tropospheric $\mathrm{O}_{3}$ in this region due to the thermal decomposition of PAN (Honrath et al., 1996; Hamlin and Honrath, 2002).

This study utilizes 2 years of continuous measurements and model results to characterize the seasonally varying magnitude of $\mathrm{O}_{3}$ and its precursors in the remote high latitude Arctic and potential impact from transported pollution. Yearround measurements of $\mathrm{NO}_{x}, \mathrm{NO}_{y}, \mathrm{PAN}, \mathrm{O}_{3}$, and $\mathrm{NMHC}$ from the high altitude Greenland Environmental Observatory at Summit (GEOSummit) station in Greenland are presented. The paper is structured as follows: in Sect. 2, the techniques to measure $\mathrm{NO}, \mathrm{NO}_{2}, \mathrm{NO}_{y}$ (total reactive nitrogen oxides $\mathrm{NO}_{y}=\mathrm{NO}+\mathrm{NO}_{2}+\mathrm{PAN}+\mathrm{HNO}_{3}+\mathrm{HONO}+$ others), PAN, and NMHC are presented and the FLEXPART Lagrangian 
particle dispersion model utilized in this study is discussed. Sect. 3.1 presents the seasonal cycles of $\mathrm{O}_{3}$ precursors at the measurements site and the $\mathrm{NO}_{y}$ speciation is investigated. In Sect. 3.2, the source contributions to enhanced $\mathrm{O}_{3}$ precursors from anthropogenic emissions and biomass burning are discussed. Finally, a summary of the main findings is given in Sect. 4.

\section{Experimental methods}

\subsection{GEOSummit station}

Measurements of $\mathrm{NO}_{x}, \mathrm{NO}_{y}, \mathrm{PAN}$, and $\mathrm{NMHC}$ were performed at the GEOSummit station (hereafter called Summit), Greenland $\left(72.34^{\circ} \mathrm{N}, 38.29^{\circ} \mathrm{W} ; 3212 \mathrm{~m}\right.$ a.s.l.), from July 2008 to July 2010. Inlets for the instruments were installed $\sim 8.5 \mathrm{~m}$ above the snowpack $(\sim 6.5 \mathrm{~m}$ toward the end of the measurement period, as a result of snow accumulation) on a meteorological tower located approximately $660 \mathrm{~m}$ south-west of the main camp within the "clean-air" sector. Tubing and cables were routed through a heated pipe to a buried laboratory facility.

\subsection{Measurements}

\subsubsection{Nitrogen oxides}

Measurements of $\mathrm{NO}, \mathrm{NO}_{2}$, and $\mathrm{NO}_{y}$ were performed with an automated $\mathrm{O}_{3}$ chemiluminescence detection system (Ridley and Grahek, 1990). The instrument was developed at Michigan Technological University and is based on the same design that was used in Newfoundland in 1996 (Peterson and Honrath, 1999), subsequently installed at Summit during campaigns in 1998, 1999, and 2000 (Honrath et al., 1999, 2002; Dibb et al., 2002), and at the Pico Mountain Observatory from 2002 to 2010 (Val Martín et al., 2006). $\mathrm{NO}_{2}$ and $\mathrm{NO}_{y}$ were detected by chemiluminescence after reduction to NO using a photolytic $\mathrm{NO}_{2}$ converter (Kley and Mcfarland, 1980) and a gold-catalyzed $\mathrm{NO}_{y}$ converter in the presence of CO (Bollinger et al., 1983; Fahey et al., 1985), respectively. $\mathrm{NO}_{y}$ is given as the sum of reactive nitrogen oxides. In the Arctic, $\mathrm{NO}_{y}$ is primarily comprised of $\mathrm{NO}, \mathrm{NO}_{2}$, $\mathrm{PAN}, \mathrm{HNO}_{3}$, nitrous acid (HONO), and particulate nitrate (p$\mathrm{NO}_{3}^{-}$). For the instrument used in this study, a photolytic blue LED NO$~_{2}$ converter (Air-Quality Design Inc., Colorado) was installed. Photolytic converters have lower conversion efficiencies than molybdenum converters; however, interferences from other species photolyzing to NO, such as HONO and PAN, are reduced (Pollack et al., 2011; Villena et al., 2012). The sample mass flow controllers (MFC) and the $\mathrm{NO}_{2}$ and $\mathrm{NO}_{y}$ converters were housed inside the inlet box on the tower to minimize the residence time of $\mathrm{NO}_{y}$ species inside the PFA (perfluoroalkoxy) tubing.

During each measurement cycle of $10 \mathrm{~min}$, the $\mathrm{NO}$ and $\mathrm{NO}_{2}$ signals were recorded as $30 \mathrm{~s}$ averages and $\mathrm{NO}_{y}$ signals as $20 \mathrm{~s}$ averages, after a period of equilibration in each mode. Zero measurements of $\mathrm{NO}$ were performed at the start and end of each measurement cycle by mixing $\mathrm{O}_{3}$ with the sample upstream of the reaction chamber. The zero signals were measured to determine the interference signal in the reaction chamber, which was then subtracted from the measured signals. Calibrations were performed every $12 \mathrm{~h}$ to determine the sensitivity of the instrument to NO via standard addition $\left(10 \mathrm{~cm}^{3} \mathrm{~min}^{-1}\right)$ of NO in nitrogen $\left(\mathrm{N}_{2}\right)$ (ranging from 0.792 to $0.930 \mathrm{mmol} \mathrm{mol}^{-1}$, Scott Marrin, Scott Specialty Gases) to the sample flow of $650 \mathrm{~cm}^{3} \mathrm{~min}^{-1}$ at the inlet on the tower. A known amount of $\mathrm{NO}_{2}$, generated via gas phase titration of $\mathrm{NO}$ with $\mathrm{O}_{3}$, was also added to the sample flow during the calibration cycle to determine the conversion efficiencies of the $\mathrm{NO}_{2}$ and $\mathrm{NO}_{y}$ converters. In addition to the standard calibrations, every 3 days the conversion efficiency of the $\mathrm{NO}_{y}$ converter to $\mathrm{HNO}_{3}$ and $n$-propyl nitrate (NPN) were determined and artifacts for $\mathrm{NO}_{y}, \mathrm{NO}$, and $\mathrm{NO}_{2}$ were measured via sampling $\mathrm{NO}_{x}$-free air (breathing air grade, Airgas, Radnor, PA, USA). The final data sets were corrected for this artifact.

Approximately $7 \%$ of the final $\mathrm{NO}$ and $\mathrm{NO}_{2}$ data sets and $8 \%$ of the final $\mathrm{NO}_{y}$ data set were removed due to known instrument issues. Additional filtering procedures were applied to remove points potentially contaminated by local camp pollution. Variability in the 20 and $30 \mathrm{~s}$ averaged data was compared to the expected value from photon counting statistics which are treated as a Poisson distribution. Measurements with variability greater than 3 times the Poisson value were then removed from the final data set $(\sim 5 \%)$. Evaluation of these periods show that they typically occur when the wind direction was from the main camp, confirming that local pollution was the main source of the variability. Erroneous data points as a result of unknown instrument issues, or periods when the skiway was groomed, were also removed. Less than $0.2 \%$ of the total data were classified as erroneous and each point was manually checked by comparing to adjacent observations. Finally, large negative mole fractions, as a result of large variability between modes during the measurement cycle, were removed $(\lesssim 1 \%)$.

The final $\mathrm{NO}, \mathrm{NO}_{2}, \mathrm{NO}_{x}$, and $\mathrm{NO}_{y}$ data used in this work were further averaged over a 30 min period. $\mathrm{NO}_{x}$ was determined as the sum of the $\mathrm{NO}$ and $\mathrm{NO}_{2}$ measurements during each $10 \mathrm{~min}$ cycle. The overall uncertainty for the 30 min data is calculated from the root sum of the squares of the measurement accuracy, artifact uncertainty, and precision. Maximum uncertainties for $\mathrm{NO}, \mathrm{NO}_{2}$, and $\mathrm{NO}_{x}$ at $50 \mathrm{pmol} \mathrm{mol}^{-1}$ are 10, 17, and $19 \%$, respectively. For $\mathrm{NO}_{y}$, the total uncertainty is also dependent on the conversion efficiencies of the $\mathrm{NO}_{y}$ species, which is estimated to be $\sim 10 \%$ based on the conversion efficiencies and $\mathrm{NO}_{y}$ levels expected at Summit. The total uncertainty in $\mathrm{NO}_{y}$ is estimated to be $\sim 12 \%$ at $200 \mathrm{pmol} \mathrm{mol}^{-1}$. Detection limits for the $30 \mathrm{~min}$ averages were estimated from the $2 \sigma$ precision of the mea- 
surements, based on the standard error of the photon counting noise. Median detection limits for $\mathrm{NO}, \mathrm{NO}_{2}, \mathrm{NO}_{x}$, and $\mathrm{NO}_{y}$ were $2.7,5.0,5.7$, and $3.8 \mathrm{pmol} \mathrm{mol}^{-1}$, respectively. Mole fractions below the detection limit, including small negative mole fractions (as a result of uncertainties in the zero measurement and artifact corrections), were included in all averaging calculations to ensure the final values were not biased. Further details on the calibrations performed and the precision and accuracy of the measurements are provided in the Supplement.

\subsubsection{Peroxyacetyl nitrate}

A commercial PAN gas chromatography analyzer (PAN-GC, Metcon, Inc., Boulder, $\mathrm{CO}$ ) was installed alongside the $\mathrm{NO}_{x y}$ instrument to determine atmospheric PAN mole fractions. The PAN instrument is based on gas chromatography with electron capture detection (GC-ECD). The instrument was equipped with a preconcentration unit to improve the detection limit whilst allowing for PAN sampling every $10 \mathrm{~min}$. The preconcentration unit traps PAN and carbon tetrachloride $\left(\mathrm{CCl}_{4}\right)$ on a Peltier-cooled $\left(5^{\circ} \mathrm{C}\right)$ capillary column with subsequent desorption at approximately $35^{\circ} \mathrm{C}$ for injection onto the main GC column, which was set to a temperature of $15^{\circ} \mathrm{C}$. Ultra-pure nitrogen gas $(99.9999 \%$ purity) was used as the carrier gas for the PAN-GC.

The instrument was calibrated approximately every week using a known concentration of PAN, which was photochemically produced from the same NO-calibration gas used for the $\mathrm{NO}_{x y}$ instrument described in Sect. 2.2.1. The PAN concentration was determined from the NO-calibration gas mixing ratio, the mass flow rates, and the conversion efficiency of NO to PAN, and varied from $\sim 520$ to $700 \mathrm{pmol} \mathrm{mol}^{-1}$, during the measurement period. The NO gas was delivered to a reaction cell inside the PAN calibration unit which contained a UV mercury lamp to photolyze an excess of acetone (in zero air) to form peroxyacetyl radicals that oxidize the $\mathrm{NO}$ gas to $\mathrm{NO}_{2}$. $\mathrm{NO}_{2}$ then reacts with peroxyacetyl radicals to form PAN. The PAN calibration gas was sent to the inlet on the tower and then sampled by the GC-ECD. The $\mathrm{NO}_{x y}$ instrument was used to determine the conversion efficiency of NO to PAN at the beginning and end of the measurement period. Some of the gas sent to the PAN inlet was redirected to the $\mathrm{NO}_{x y}$ instrument and the $\mathrm{NO}$ and $\mathrm{NO}_{2}$ levels were measured with the PAN calibration unit switched on and off. The conversion efficiency remained relatively constant throughout the measurement period at $93 \pm 3 \%$ (mean \pm uncertainty).

Uncertainty in the PAN calibration is associated with uncertainties in (a) the calculation of the NO addition, (b) the conversion of NO to PAN in the calibration unit, and (c) variability in the PAN peak areas during the calibration. The root mean squared propagation of error gives an uncertainty in the calibration standard of $16 \%$ during normal operation. The sensitivities determined from the weekly PAN calibra- tions were interpolated to the measurements to take into account any drifting. Additional uncertainty arises from shortterm variability in sensitivity between calibrations. $\mathrm{CCl}_{4}$ was used as an internal reference during periods when calibrations were not taken (Karbiwnyk et al., 2003). The atmospheric concentration of $\mathrm{CCl}_{4}$ is relatively constant; therefore, any changes in the $\mathrm{CCl}_{4}$ peak area are primarily caused by changes in the instrument sensitivity. The median relative standard deviation (RSD) of the $\mathrm{CCl}_{4}$ peak area between calibrations was $6 \%$. During a period between 14 February 2009 and 25 May 2009 there was a gap in the calibrations caused by a blockage in the tubing that delivered the PAN calibration gas to the inlet. To estimate PAN sensitivities during this period, the calibrations before and after the blockage were used to perform a linear regression between the PAN sensitivities and the $\mathrm{CCl}_{4}$ peak areas. The slope and intercept from the regression were then used to determine the PAN sensitivities from the $\mathrm{CCl}_{4}$ peak areas between 14 February 2009 and 25 May 2009. An additional uncertainty in the PAN measurements of $12 \%$ (median RSD) was estimated from errors in the regression. The total uncertainty in the PAN calibration is determined from the root sum of the squares of the uncertainties in the calibrations and the variability, giving an uncertainty of $17 \%$ during normal operation, and $21 \%$ during spring 2009.

The limit of detection (LOD) of the instrument was estimated from the peak to baseline noise ratio. The LOD is defined as the mole fraction giving a signal-to-noise $(\mathrm{S} / \mathrm{N})$ ratio of 3. The noise level was determined as the peak-topeak value of the baseline noise from a region just after the PAN peak, for each chromatogram. The limit of detection was the highest during the first few months of operation with a LOD up to $75 \mathrm{pmol} \mathrm{mol}^{-1}$ in September 2008. The LOD improved after November 2008, decreasing to around 20-40 $\mathrm{pmol} \mathrm{mol}^{-1}$ from April 2009 to late January 2010. In spring 2010 , the LOD increased to $\sim 40-65 \mathrm{pmol} \mathrm{mol}^{-1}$ as a result of drifting and a noisy baseline as the detector became dirty. Due to the degradation of the detector, no data after 28 April 2010 were included in the analyses here.

Similarly to the $\mathrm{NO}_{x}$ and $\mathrm{NO}_{y}$ data, the PAN measurements were averaged over $30 \mathrm{~min}$. The total uncertainty for the $30 \mathrm{~min}$ averaged PAN mole fractions was determined from the root sum of the squares of the measurement precision (estimated as $2 \sigma N^{0.5}$, where $N$ is the number of points averaged in $30 \mathrm{~min}(N \leq 3)$ ) and from the uncertainty in the calibration. The precision was typically $<26 \mathrm{pmol} \mathrm{mol}^{-1}$ with a mean (median) value of $6.5 \mathrm{pmol} \mathrm{mol}^{-1}\left(5.3 \mathrm{pmol} \mathrm{mol}^{-1}\right)$. Using the median precision, the total uncertainty in the PAN measurements at $100 \mathrm{pmol} \mathrm{mol}^{-1}$ was estimated to be approximately $18 \%$ during normal operation, and $22 \%$ during spring 2009 . For the statistical analyses presented here, 30 min averages below the LOD were treated as one-half of the limit of detection. Despite the high LOD, $\sim 74 \%$ of the 30 min averaged PAN data were above the LOD during 2008, and $>99 \%$ were 
above the LOD from 2009 onwards. The final PAN data set was not filtered for wind direction as analyses showed that there was no obvious influence from camp pollution on the PAN measurements.

\subsubsection{Non-methane hydrocarbons}

NMHC were continuously sampled from June 2008 to July 2010 using a fully automated and remotely controlled GC system that was specifically designed for this study. Details of the set-up at Summit are given in Helmig et al. (2014). The GC is a further development of the instrument operated at the Pico Mountain Observatory and described in detail by Tanner et al. (2006). The NMHC system provided approximately eight ambient measurements of $\mathrm{C}_{2}-\mathrm{C}_{6}$ hydrocarbons each day, with each measurement representing a collection/sample integration time during the sample prefocusing step of $\sim 45 \mathrm{~min}$. In addition, one blank sample was analyzed $\sim$ daily, and a standard approximately every 2 days.

The inlet for the GC instrument was installed on the same tower as the PAN, $\mathrm{NO}_{y}$, and $\mathrm{NO}_{x}$ inlets. The instrument relied on a cryogen-free sample enrichment and injection system. All consumable gases were prepared at the site with a hydrogen generator, compressor, and air purification system. Aliquots of the sample stream were first passed through a Peltier-cooled trap to dry the air to a dew point of $-30^{\circ} \mathrm{C}$, then through an ozone scrubber, and $\mathrm{NMHC}$ were then concentrated on a Peltier-cooled $\left(-25^{\circ} \mathrm{C}\right)$ multi-stage adsorbent trap. Analysis was accomplished by thermal desorption and injection onto an aluminum oxide $\left(\mathrm{Al}_{2} \mathrm{O}_{3}\right)$ porous layer open tubular (PLOT) column for cryogen-free separation on a SRI Model 8610 GC with flame ionization detection (FID). Blanks and standard samples were injected regularly from the manifold. The gravimetric and whole air standards that were used were cross-referenced against our laboratory scale for volatile organic compounds, which has been cross-referenced against national and international scales, including through two previous audits by the World Calibration Centre for Volatile Organic Compounds (WCC-VOC) (http://imk-ifu.fzk.de/wcc-voc/). At 100 pptv mole fraction, analytical accuracy and precision were typically better than $3-5 \%$, yielding a combined uncertainty estimate of $\sim 5 \%$. The instrument achieved low single digit pmol mol ${ }^{-1}$ detection limits. During summer, when NMHC levels for $\mathrm{C}_{4}-$ $\mathrm{C}_{5} \mathrm{NMHC}$ at times dropped below the detection limits, for the statistical and whisker plot calculations those data were treated as one-half of the detection limit.

\subsubsection{Ozone}

Surface $\mathrm{O}_{3}$ was measured by an $\mathrm{O}_{3}$ analyzer located in the Temporary Atmospheric Weather Observatory (TAWO) building a few hundred metres from camp by the National Oceanic and Atmospheric Administration (NOAA) as part of the core atmospheric measurements that began in 2000
(Petropavlovskikh and Oltmans, 2012). Hourly averaged data for 2008, 2009, and 2010 were downloaded from the Earth System Research Laboratory Global Monitoring Division (ESRL-GMD) website (http://www.esrl.noaa.gov/gmd/ dv/data/).

\subsubsection{FLEXPART}

The Lagrangian particle dispersion model FLEXPART (version 8.2) was utilized to identify potential periods when polluted air masses impacted the measurement site. FLEXPART simulates atmospheric transport using wind fields from global forecast models to determine source to receptor pathways of air masses (Stohl et al., 2005). The model was driven with meteorological analysis data from the European Centre for Medium-Range Weather Forecasts (ECMWF) and ran backward in time in so-called "retroplume" mode (Stohl et al., 2003). Every 3 h, 40000 particles were released from the measurement site location and followed backwards in time for 20 days. Sensitivities to anthropogenic and fire emissions were determined during the backwards simulations and are proportional to the particle residence time over the source areas. In this work, a black carbon tracer was used to simulate both anthropogenic $\left(\mathrm{BC}_{\mathrm{anthro}}\right)$ and biomass burning emissions $\left(\mathrm{BC}_{\text {fire }}\right)$. For the $\mathrm{BC}$ anthropogenic tracer the Emissions Database for Global Atmospheric Research (EDGAR) UNEP BC report 2005 data (UNEP, 2011; Shindell et al., 2012) were used. To estimate the BC fire emissions, MODIS hot spot data (Justice et al., 2002; Giglio et al., 2003) were used to estimate the area burned $(180 \mathrm{hPa}$ per MODIS hot spot) and combined with a combustion efficiency, emission factor, and fuel load, which were all based on land use type (Stohl et al., 2006). The land surface types are taken from the NOAH Land Surface Model version 2.7.1. Other factors are provided in Table S1 in the Supplement. The BC tracer was susceptible to both wet and dry deposition during transport. The wet scavenging coefficient used in the model is more representative of a hydrophilic aerosol; however, there is no conversion from hydrophobic to hydrophilic properties with aging $\mathrm{BC}$ in the model; therefore, greater scavenging may occur closer to the source region, resulting in an underestimation of the BC tracer at Summit (Stohl et al., 2013). However, for this study the tracer was only used to identify events; therefore, absolute BC values were not required. Carbon monoxide can also be used as a tracer for pollution transport. Simulations using $\mathrm{CO}$ were performed for the anthropogenic tracer; however, the $\mathrm{BC}$ tracer was used in this study as simulations were available for both anthropogenic and fire tracers as part of the POLARCAT campaign, and thus allowed for consistency between the biomass burning and anthropogenic analysis. A comparison was made between the $\mathrm{CO}$ and $\mathrm{BC}$ anthropogenic tracers to determine whether pollution events were missed when using the $\mathrm{BC}$ tracer, as a result of deposition. A time series and correlation plot for the two tracers from summer 2008 to 2010 are shown in 
Figs. S1 and S2 in the Supplement. The result suggests that although there may be some differences in the magnitude of the FLEXPART tracers, the transport simulated with the BC tracer correlates well with the CO tracer (Pearson's correlation coefficient, $R=0.97$ ); therefore, significant pollution events were unlikely to be missed.

\section{Results and discussion}

\subsection{Seasonal cycles}

\subsubsection{Reactive nitrogen oxides}

Figure 1a-d show the statistical analyses of the monthly averaged $\mathrm{NO}_{y}, \mathrm{NO}_{x}, \mathrm{PAN}$, and $\mathrm{O}_{3}$ ambient mole fractions, during the measurement period from July 2008 to July 2010. A malfunction with the $\mathrm{NO}_{x y}$ instrument resulted in missing $\mathrm{NO}_{x}$ and $\mathrm{NO}_{y}$ data from 24 November 2008 to 30 March 2009. Seasonal cycles are observed for all measured species, with higher levels during the late winter-early spring period and lower mole fractions from summer to fall. The positively skewed whiskers indicate that air masses with elevated levels of $\mathrm{NO}_{x}, \mathrm{NO}_{y}$, and PAN were sampled yearround. Anthropogenic and biomass burning emissions transported to the site from North America and Europe are a major source of these enhancements (see Sect. 3.2). Observations from the Arctic Research of the Composition of the Troposphere from Aircraft and Satellites (ARCTAS) mission in 2008 showed that mixed stratospheric-tropospheric air masses, above $5 \mathrm{~km}$, have elevated levels of $\mathrm{O}_{3}$ precursors such as $\mathrm{NO}_{x}$ and $\mathrm{HNO}_{3}$, which can subsequently be converted to PAN (Liang et al., 2011). Therefore, high mole fractions observed in $\mathrm{PAN}, \mathrm{NO}_{y}$, and $\mathrm{NO}_{x}$, may also be the result of sampling air masses mixed with those originating from the stratosphere and upper-troposphere.

Table 1 gives a statistical summary for the monthly averages of PAN, $\mathrm{NO}_{y}, \mathrm{NO}_{x}$, and $\mathrm{O}_{3}$ during 2008-2010. Maxima in monthly mean mole fractions of PAN occur in April with mean levels of $217 \pm 65(1 \sigma) \mathrm{pmol} \mathrm{mol}^{-1}$ and $273 \pm 100 \mathrm{pmol} \mathrm{mol}^{-1}$, for 2009 and 2010 , respectively. The difference between monthly mean PAN levels observed in April 2010 and April 2009 are within the measurement uncertainties (as shown in Fig. S3, Supplement), however, the $30 \mathrm{~min}$ averages (shown in Fig. S4) indicate high levels of PAN, $\mathrm{NO}_{y}$, and $\mathrm{NO}_{x}$ in April 2010. These high levels are explored further in Sect. 3.2.1. Monthly mean $\mathrm{NO}_{y}$ mole fractions also peaked during April 2010 at $352 \pm 102 \mathrm{pmol} \mathrm{mol}^{-1}$. PAN mole fractions at Summit and the magnitude of the PAN springtime peak are consistent with observations at other high latitude sites such as Zeppelin Mountain, Svalbard (Beine et al., 1997; Solberg et al., 1997; Beine and Krognes, 2000), and Alert, Northwest Territories, Canada (Worthy et al., 1994; Dassau et al., 2004). PAN levels in September 2008 were very low and typically

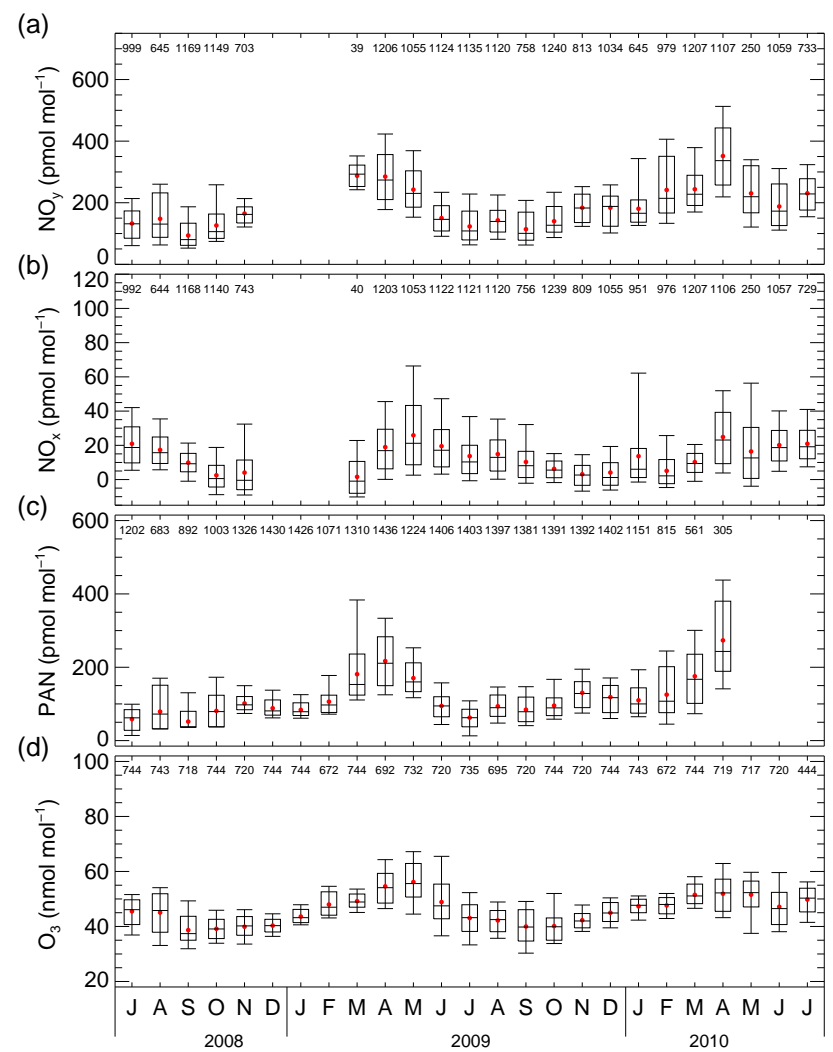

Figure 1. Monthly averages of (a) $\mathrm{NO}_{x}$, (b) $\mathrm{NO}_{y}$, (c) PAN, and (d) $\mathrm{O}_{3}$ at Summit from July 2008 to July 2010. The median and mean of the data are represented by a horizontal line and filled black circle, respectively; the box indicates the middle $67 \%$ of the data; and the vertical whiskers indicate the 5th and 95th percentile of all the data. The numbers at the top of each plot represent the number of $30 \mathrm{~min}$ averages included in the distribution.

below the detection limit as a result of a noisy baseline. In 2009, PAN reached a monthly minimum of $63 \mathrm{pmol} \mathrm{mol}^{-1}$ in July. $\mathrm{NO}_{y}$ mole fractions did not decrease as quickly as PAN from spring to summer in 2009 and reached a minimum monthly average during September. We find that the PAN and $\mathrm{NO}_{y}$ summer mole fractions observed here are comparable to previous measurements performed at the same site in 1998 and 1999, when observed PAN levels were typically 20-150 $\mathrm{pmol} \mathrm{mol}^{-1}$, and $\mathrm{NO}_{y}$ levels ranged between 100 and $300 \mathrm{pmol} \mathrm{mol}^{-1}$ (Honrath et al., 1999; Ford et al., 2002). The slower decrease in $\mathrm{NO}_{y}$ from spring to summer, compared to PAN, is a result of the presence of $\mathrm{NO}_{x}$ and odd $\mathrm{NO}_{y}$ (odd $\mathrm{NO}_{y}=\mathrm{NO}_{y}-\mathrm{PAN}-\mathrm{NO}_{x}$ ) over the summer months and is discussed further below.

The seasonal cycle of PAN is governed by the rate of thermal decomposition and transport patterns. The warmer summer temperatures result in the decomposition of PAN during long-range transport; additionally, during the summer months the polar front recedes north, thus reducing the potential for anthropogenic emissions to reach the measurement 
Table 1. Monthly statistics for $\mathrm{NO}_{x}, \mathrm{NO}_{y}, \mathrm{PAN}, \mathrm{O}_{3}$, and the $\mathrm{NO}_{y}$ budget measured at Summit from 2008 to 2010.

\begin{tabular}{|c|c|c|c|c|c|c|c|}
\hline Year & Month & $\begin{array}{c}\mathrm{NO}_{x} \\
\left(\mathrm{pmol} \mathrm{mol}^{-1}\right) \\
\text { Mean } \pm \mathrm{SD}\end{array}$ & $\begin{array}{c}\mathrm{NO}_{y} \\
\left(\mathrm{pmol} \mathrm{mol}^{-1}\right) \\
\text { Mean } \pm \mathrm{SD}\end{array}$ & $\begin{array}{c}\text { PAN } \\
\left(\mathrm{pmol} \mathrm{mol}^{-1}\right) \\
\text { Mean } \pm \mathrm{SD}\end{array}$ & $\begin{array}{c}\mathrm{O}_{3} \\
\left(\mathrm{pmol} \mathrm{mol}^{-1}\right) \\
\text { Mean } \pm \mathrm{SD}\end{array}$ & $\begin{array}{c}\mathrm{NO}_{x} / \mathrm{NO}_{y}{ }^{*} \\
\% \\
\text { Mean } \pm \mathrm{SD}\end{array}$ & $\begin{array}{c}\mathrm{PAN} / \mathrm{NO}_{y}{ }^{*} \\
\% \\
\text { Mean } \pm \mathrm{SD}\end{array}$ \\
\hline \multirow[t]{6}{*}{2008} & Jul & $21 \pm 18$ & $133 \pm 47$ & $59 \pm 27$ & $46 \pm 5$ & $15 \pm 7$ & $42 \pm 14$ \\
\hline & Aug & $17 \pm 9$ & $148 \pm 66$ & $79 \pm 53$ & $45 \pm 7$ & $13 \pm 5$ & $49 \pm 17$ \\
\hline & Sep & $10 \pm 7$ & $94 \pm 42$ & $52 \pm 31$ & $39 \pm 5$ & $9 \pm 7$ & $51 \pm 13$ \\
\hline & Oct & $2 \pm 10$ & $126 \pm 57$ & $81 \pm 48$ & $39 \pm 4$ & $1 \pm 6$ & $58 \pm 19$ \\
\hline & Nov & $4 \pm 16$ & $165 \pm 35$ & $101 \pm 22$ & $40 \pm 4$ & $0 \pm 5$ & $58 \pm 10$ \\
\hline & Dec & - & - & $88 \pm 27$ & $40 \pm 2$ & - & - \\
\hline \multirow[t]{12}{*}{2009} & Jan & - & - & $84 \pm 20$ & $44 \pm 3$ & - & - \\
\hline & Feb & - & - & $106 \pm 44$ & $48 \pm 4$ & - & - \\
\hline & Mar & $2 \pm 11$ & $288 \pm 36$ & $181 \pm 77$ & $49 \pm 3$ & $0 \pm 4$ & $56 \pm 3$ \\
\hline & Apr & $19 \pm 18$ & $285 \pm 77$ & $217 \pm 65$ & $55 \pm 6$ & $7 \pm 5$ & $76 \pm 11$ \\
\hline & May & $26 \pm 19$ & $242 \pm 64$ & $170 \pm 41$ & $56 \pm 7$ & $11 \pm 7$ & $72 \pm 10$ \\
\hline & Jun & $19 \pm 15$ & $150 \pm 43$ & $94 \pm 31$ & $49 \pm 8$ & $13 \pm 8$ & $63 \pm 12$ \\
\hline & Jul & $14 \pm 18$ & $123 \pm 55$ & $63 \pm 26$ & $43 \pm 6$ & $11 \pm 12$ & $51 \pm 15$ \\
\hline & Aug & $15 \pm 13$ & $143 \pm 41$ & $94 \pm 29$ & $42 \pm 4$ & $10 \pm 8$ & $64 \pm 10$ \\
\hline & Sep & $10 \pm 13$ & $114 \pm 45$ & $84 \pm 33$ & $40 \pm 6$ & $9 \pm 8$ & $72 \pm 12$ \\
\hline & Oct & $6 \pm 8$ & $140 \pm 43$ & $95 \pm 32$ & $40 \pm 5$ & $5 \pm 7$ & $70 \pm 9$ \\
\hline & Nov & $3 \pm 7$ & $184 \pm 40$ & $130 \pm 36$ & $42 \pm 3$ & $1 \pm 3$ & $65 \pm 7$ \\
\hline & Dec & $4 \pm 14$ & $184 \pm 55$ & $119 \pm 42$ & $45 \pm 3$ & $1 \pm 5$ & $66 \pm 16$ \\
\hline \multirow[t]{7}{*}{2010} & Jan & $14 \pm 25$ & $181 \pm 59$ & $110 \pm 41$ & $47 \pm 3$ & $3 \pm 4$ & $55 \pm 10$ \\
\hline & Feb & $5 \pm 10$ & $241 \pm 89$ & $125 \pm 63$ & $48 \pm 3$ & $2 \pm 4$ & $50 \pm 12$ \\
\hline & Mar & $10 \pm 10$ & $244 \pm 66$ & $175 \pm 73$ & $51 \pm 4$ & $4 \pm 4$ & $73 \pm 20$ \\
\hline & Apr & $25 \pm 17$ & $352 \pm 102$ & $273 \pm 100$ & $52 \pm 6$ & $7 \pm 4$ & $72 \pm 11$ \\
\hline & May & $16 \pm 18$ & $230 \pm 67$ & - & $52 \pm 6$ & - & - \\
\hline & Jun & $20 \pm 12$ & $188 \pm 63$ & - & $47 \pm 7$ & - & - \\
\hline & Jul & $21 \pm 11$ & $231 \pm 52$ & - & $50 \pm 5$ & - & - \\
\hline
\end{tabular}

* PAN / $\mathrm{NO}_{y}$ and $\mathrm{NO}_{x} / \mathrm{NO}_{y}$ ratios determined using coincident measurements only.

site (Beine and Krognes, 2000; Stohl, 2006). Measurements have shown that PAN is typically the largest contributor to $\mathrm{NO}_{y}$ in the Arctic, due to the rapid formation of PAN near the source region and a long lifetime in the free troposphere (Solberg et al., 1997; Munger et al., 1999; Ford et al., 2002; Alvarado et al., 2010; Singh et al., 2010; Liang et al., 2011). However, there have been very few studies on the seasonal variability of the $\mathrm{NO}_{y}$ speciation in the Arctic due to limited measurements over winter months.

The full annual cycle of $\mathrm{NO}_{y}$ contributions from PAN and $\mathrm{NO}_{x}$ during this study provides some information on the $\mathrm{NO}_{y}$ speciation, year-round, at Summit. Table 1 shows that PAN is the dominant form of $\mathrm{NO}_{y}$ all year, with monthly mean $[\mathrm{PAN}] /\left[\mathrm{NO}_{y}\right]$ ratios above $50 \%$ in spring and fall, reaching a maximum of $76 \%$ in April 2009. The lowest $[\mathrm{PAN}] /\left[\mathrm{NO}_{y}\right]$ ratios occurred during the summer, with a minimum monthly mean of $42 \%$ in July 2008 . The seasonal cycle for $\mathrm{NO}_{x}$ does not follow PAN and $\mathrm{NO}_{y}$ at Summit. As shown in Table 1, monthly mean $\mathrm{NO}_{x}$ levels peak 1 month later than $\mathrm{NO}_{y}$ and PAN, coinciding with an increase in solar radiation. Thus, the contribution of $\mathrm{NO}_{x}$ to $\mathrm{NO}_{y}$ maximizes over the summer (10-15\%). The monthly average $\mathrm{NO}_{x}$ contribution decreased to $\lesssim 3 \%$ over winter and typically $\mathrm{NO}_{x}$ levels were below the detection limit of the instrument. The thermal decomposition of PAN is a possible local source of ambient $\mathrm{NO}_{x}$ during spring and summer months (Beine et al., 1997); however, the ambient temperatures during the measurement period were always below freezing. The PAN lifetime at Summit is nearly 2 days at $0{ }^{\circ} \mathrm{C}$ (Sander et al., 2013); therefore, the contribution to $\mathrm{NO}_{x}$ from thermal decomposition at the site is expected to be very low.

Studies have hypothesized that photochemical reactions within the snowpack result in the release of $\mathrm{NO}_{x}$ and also HONO to the overlying atmosphere (e.g. Honrath et al., 1999, 2000a, b, 2002; Munger et al., 1999; Beine et al., 2002; Dibb et al., 2002; Dominé and Shepson, 2002; Beine et al., 2003; Grannas et al., 2007; Thomas et al., 2011). Thus, the increase of ambient $\mathrm{NO}_{x}$ with radiation in spring suggests a possible photochemical source. The diurnal cycles of ambient $\mathrm{NO}_{x}$ at Summit (discussed further below) also indicate a photochemical source of $\mathrm{NO}_{x}$ from the snowpack.

Figure 2 shows the monthly averaged mole fractions of $\mathrm{NO}_{y}$ and $\mathrm{PAN}+\mathrm{NO}_{x}$ during the measurement period. The results show that the sum of PAN and $\mathrm{NO}_{x}$ cannot always 


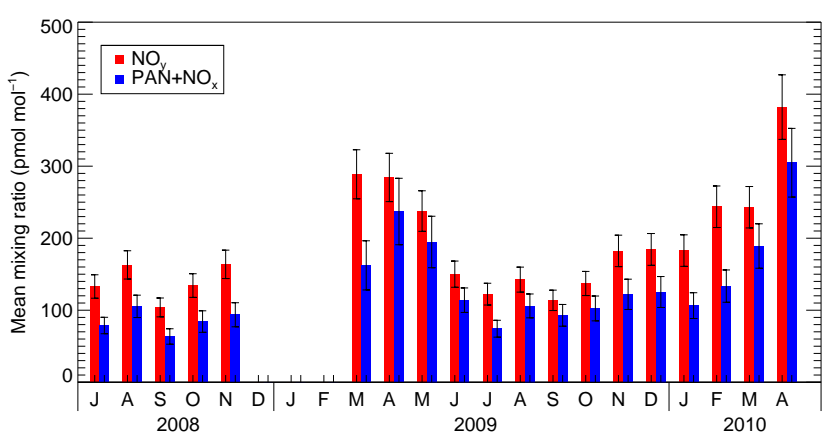

Figure 2. Monthly mean levels of $\mathrm{NO}_{y}$ and $\mathrm{PAN}+\mathrm{NO}_{x}$ at Summit calculated from individual $30 \mathrm{~min}$ averages for 2008-2010 at Summit. Error bars represent uncertainty in the measurements resulting from measurement accuracy, calibration uncertainty, and artifact corrections as discussed in Sects. 2.2.1, 2.2.2, and the Supplement. Uncertainties in $\mathrm{PAN}+\mathrm{NO}_{x}$ were determined from the propagation of errors. Only coincident data are considered in this analysis.

account for the monthly averaged $\mathrm{NO}_{y}$ within the measurement uncertainty range, suggesting a significant source of odd $\mathrm{NO}_{y}$ at Summit. When considering the $30 \mathrm{~min}$ averages above the limit of detection for $\mathrm{NO}_{x}, \mathrm{NO}_{y}$, and PAN, $\sim 46 \%$ of the data show significant odd $\mathrm{NO}_{y}$ levels (i.e. cannot be accounted for by total measurement uncertainty alone). What is particularly striking about the $\mathrm{NO}_{y}$ speciation is that odd $\mathrm{NO}_{y}$ levels can be very large over winter (Fig. 3). The monthly mean odd $\mathrm{NO}_{y}$ reached $110 \pm 37 \mathrm{pmol} \mathrm{mol}^{-1}$ (mean \pm uncertainty) in February 2010. The peak in odd $\mathrm{NO}_{y}$ was in March 2009 at $126 \pm 48 \mathrm{pmol} \mathrm{mol}^{-1}$; however, the data may be bias as there were only 34 coincident $\mathrm{NO}_{x}, \mathrm{NO}_{y}$, and PAN measurements in March 2009, whereas there were between $\sim 270$ and 1200 coincident measurements during the other months. Odd $\mathrm{NO}_{y}$ decreased to $\sim 20$ $60 \mathrm{pmol} \mathrm{mol}^{-1}$ over the summer months; however, this still accounts for up to $\sim 40 \%$ of the total $\mathrm{NO}_{y}$ during this period. Snowfall rates increase during the summer months at Summit (Dibb and Fahnestock, 2004); therefore, an increase in deposition of water-soluble species such as $\mathrm{HNO}_{3}$ to the snowpack may result in the depletion of ambient odd $\mathrm{NO}_{y}$ in the summer. The increase in solar radiation may also play an important role in the reduction of odd $\mathrm{NO}_{y}$ species in the summer. Solberg et al. (1997) observed a decrease in odd $\mathrm{NO}_{y}$ with increasing solar UV radiation in Spitsbergen, Norway. The authors suggested that species such as $\mathrm{HONO}, \mathrm{HNO}_{3}$, $\mathrm{NO}_{3}, \mathrm{~N}_{2} \mathrm{O}_{5}, \mathrm{HO}_{2} \mathrm{NO}_{2}$, and alkyl nitrates may contribute to $\mathrm{NO}_{y}$ over the winter with the impact reducing in spring due to an increase in photolysis. A study on the seasonal variability of alkyl nitrates at Summit in 1998-1999 found that the light $\mathrm{C}_{1}-\mathrm{C}_{4}$ alkyl nitrates peaked over winter (Swanson et al., 2003). The monthly mean total $\mathrm{C}_{1}-\mathrm{C}_{4}$ mole fraction during February 1999 was $33 \mathrm{pmol} \mathrm{mol}^{-1}$. Assuming a similar level during February 2010, alkyl nitrates would account

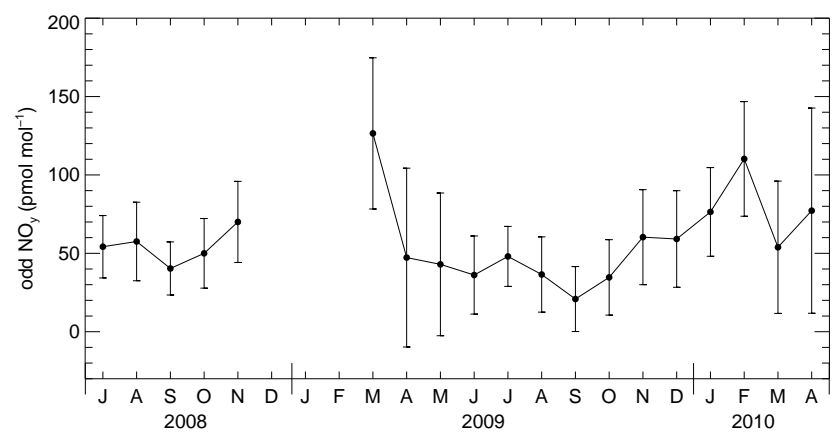

Figure 3. Monthly levels of odd $\mathrm{NO}_{y}$ (calculated from the $30 \mathrm{~min}$ averaged $\mathrm{NO}_{y}, \mathrm{PAN}$, and $\mathrm{NO}_{x}$ measurements) at Summit. Error bars represent the uncertainty in odd $\mathrm{NO}_{y}$ mole fractions, determined from the propagation of errors from PAN, $\mathrm{NO}_{x}$, and $\mathrm{NO}_{y}$.

for $\sim 1 / 3$ of the odd $\mathrm{NO}_{y}$ observed during this month. Taking into account measurement uncertainties, there remains, therefore, a large fraction of $\mathrm{NO}_{y}$ unaccounted for over winter.

Results from this study show, despite the odd $\mathrm{NO}_{y}$ levels decreasing from late spring to summer, odd $\mathrm{NO}_{y}$ species can contribute over twice as much as $\mathrm{NO}_{x}$ to the total $\mathrm{NO}_{y}$ in summer. To investigate the source of the odd $\mathrm{NO}_{y}$ species and the possible impact from snowpack photochemistry, we analyzed the ambient diurnal variability of $\mathrm{NO}_{x}, \mathrm{NO}_{y}$, and odd $\mathrm{NO}_{y}$ at Summit separately for March, April, May, and June 2008-2010 (Fig. 4).

A clear diurnal cycle is observed in the $\mathrm{NO}_{x}, \mathrm{NO}_{y}$, and odd $\mathrm{NO}_{y}$ measurements in April and May. The $\mathrm{NO}_{x}$ diurnal cycle shows a minimum in the morning and peaks after solar noon. Diurnal cycles for $\mathrm{NO}$ and $\mathrm{NO}_{2}$ are given separately in the Supplement and show NO similarly peaking around solar noon. In contrast, $\mathrm{NO}_{2}$ levels reach a maximum overnight. The observed $\mathrm{NO}_{x}$ cycle is in agreement with the cycle observed at Summit during summer 2000 (Honrath et al., 2002), which was attributed to photochemical reactions in the snowpack and enhanced vertical mixing during the day. Studies have shown that diurnally varying radiation at Summit can result in heating at the surface and the development of unstable to near-neutral conditions (Cullen and Steffen, 2001) and increasing boundary layer depths during the day (Helmig et al., 2002; Cohen et al., 2007), with entrained air having the effect of diluting snowpack emissions near the surface. Consequently, increased mixing may offset increased daytime surface fluxes or production rates and dampen or offset diurnal concentration cycles in the surface layer.

The amplitude of the diurnal cycles (determined as the difference between the minimum and maximum $2 \mathrm{~h}$ median values) was always greater for $\mathrm{NO}_{y}$ than $\mathrm{NO}_{x}$ from March to June. The $\mathrm{NO}_{y}$ and $\mathrm{NO}_{x}$ amplitudes were the largest in May, with values of 35 and $22 \mathrm{pmol} \mathrm{mol}^{-1}$, respectively. The diurnal cycle for odd $\mathrm{NO}_{y}$ in May was $20 \mathrm{pmol} \mathrm{mol}^{-1}$, peaking around solar noon (Fig. 4k), suggesting a photochemically 

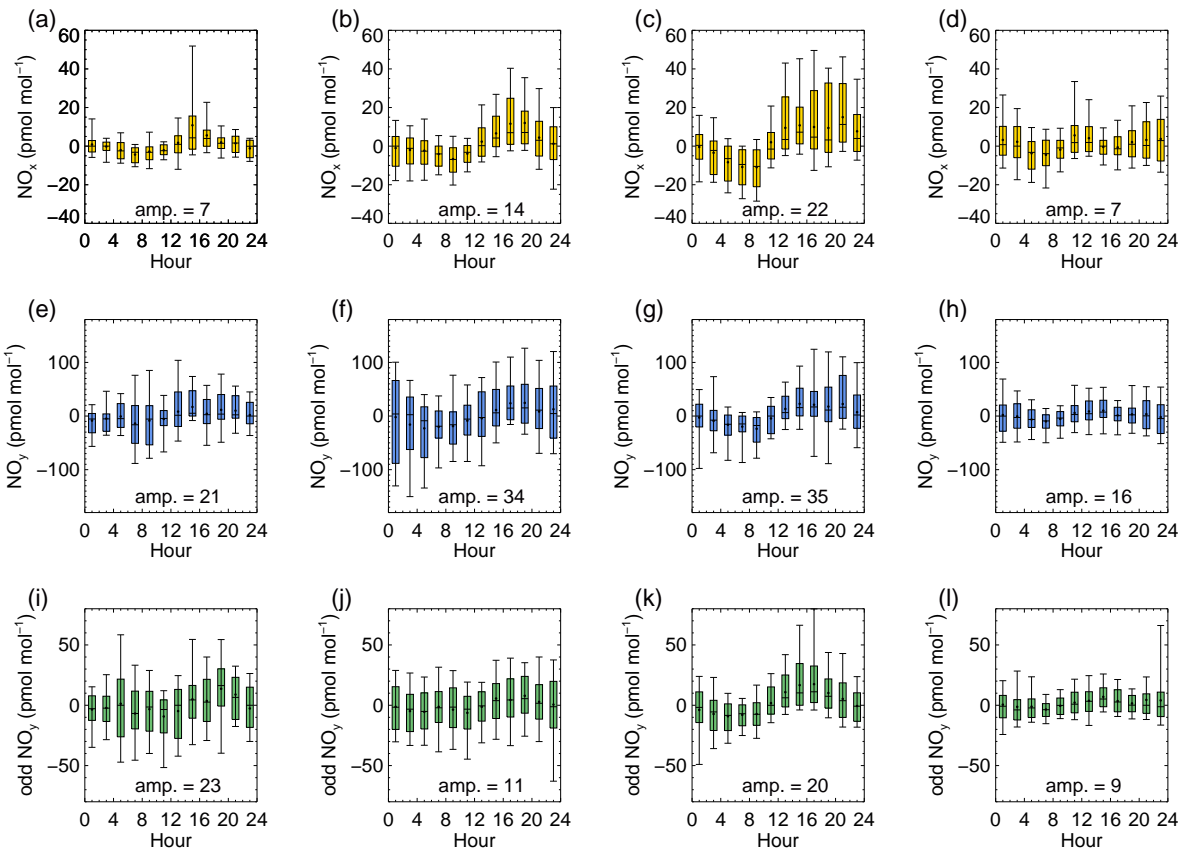

Figure 4. Average diurnal cycle of ambient $\mathrm{NO}_{x}(\mathbf{a}, \mathbf{b}, \mathbf{c}, \mathbf{d}), \mathrm{NO}_{y}(\mathbf{e}, \mathbf{f}, \mathbf{g}, \mathbf{h})$, and odd $\mathrm{NO}_{y}(\mathbf{i}, \mathbf{j}, \mathbf{k}, \mathbf{l})$ measured at Summit for the months March (1st column), April (2nd column), May (3rd column), and June (4th column) 2008-2010. Median ambient levels observed each day were subtracted, to remove any impact from day to day variability. The median and mean of the data are represented by a horizontal line, and filled black circle, respectively; the box indicates the middle $67 \%$ of the data; and the vertical whiskers indicate the 5th and 95 th percentile of all the data. Times are shown as local time (UTC). The amplitude of the diurnal cycle (given as the difference between the lowest and highest $2 \mathrm{~h}$ median values, in pmol mol${ }^{-1}$ ) is noted on each subplot.

produced odd $\mathrm{NO}_{y}$ species may be present. It has been hypothesized that $\mathrm{HNO}_{3}$ and $\mathrm{HONO}$ may account for some of the $\mathrm{NO}_{y}$ diurnal variability at Summit (Ford et al., 2002). At Neumayer, Antarctica, the diurnal variability in $\mathrm{NO}_{y}$ was attributed to both boundary layer changes and snowpack-air exchange of gases (Weller et al., 1999; Grannas et al., 2007). There is a possible contribution to the odd $\mathrm{NO}_{y}$ diurnal cycle in the summer at Summit from long-range transport of pollution. Reactive nitrogen species such as $\mathrm{HNO}_{3}$ and alkyl nitrates as these species have previously been observed in anthropogenic and biomass burning plumes in the Arctic (Liang et al., 2011; Wespes et al., 2012) and the downward transportation of pollution from aloft due to a growing boundary layer may result in a daytime maxima in $\mathrm{NO}_{x}$ and $\mathrm{NO}_{y}$, which then decreases at night due to surface uptake.

Ambient $\mathrm{HNO}_{3}$ and $\mathrm{HONO}$ have been measured at Summit during a number of spring and summer campaigns. Levels of $\mathrm{HNO}_{3}$ are typically on the order of a few tens of pmol mol${ }^{-1}$, and HONO levels are lower with mole fractions of $\sim 10 \mathrm{pmol} \mathrm{mol}^{-1}$ or less (Dibb et al., 1994, 1998, 2002, 2007; Honrath et al., 1999; Ford et al., 2002; Yang et al., 2002; Chen et al., 2007; Liao et al., 2011). Median mixing ratios of $\mathrm{HNO}_{3}$ and $\mathrm{HONO}$, measured during May and June 2010, with a mist chamber/ion chromatography (MC/IC) system $(\sim 1.5 \mathrm{~m}$ above the snowpack), were 7 and $13 \mathrm{pmolmol}^{-1}$, respectively (J. E. Dibb and M. G. Hast- ings, personal communication, 2014). Note that HONO measurements by $\mathrm{MC} / \mathrm{IC}$ in polar regions should be viewed as an upper limit to the true value, due to potential interferences from other species (Chen et al., 2004; Liao et al., 2006). A direct comparison of $\mathrm{HNO}_{3}$ and $\mathrm{HONO}$ with calculated odd $\mathrm{NO}_{y}$ levels is not possible for 2010 because PAN measurements were unavailable after April. Monthly mean odd $\mathrm{NO}_{y}$ levels calculated for May and June in 2009 were 43 and $36 \mathrm{pmol} \mathrm{mol}^{-1}$, respectively. Summer levels of alkyl nitrates are expected to be low at Summit with Swanson et al. (2003) measuring monthly mean levels (total $\mathrm{C}_{1}-\mathrm{C}_{4}$ ) of $\sim 10-20 \mathrm{pmol} \mathrm{mol}^{-1}$ between May and August. Assuming alkyl nitrate levels of $\sim 15 \mathrm{pmol} \mathrm{mol}^{-1}$ during May/June, the sum of $\mathrm{HNO}_{3}+\mathrm{HONO}+$ alkyl nitrates are comparable to the odd $\mathrm{NO}_{y}$ levels measured at Summit, in May/June (when considering measurement uncertainties). Particulate nitrate may also contribute a small amount to the total $\mathrm{NO}_{y}$; however, this contribution is expected to be small as ambient p$\mathrm{NO}_{3}^{-}$levels are typically lower than $\mathrm{HNO}_{3}$ at Summit (Dibb et al., 1994).

$\mathrm{HO}_{2} \mathrm{NO}_{2}$, may also contribute to the odd $\mathrm{NO}_{y}$ measured at Summit. The partitioning of $\mathrm{HO}_{2} \mathrm{NO}_{2}$ between air and ice has a strong temperature dependence (Ulrich et al., 2012) and a recent study in Antarctica, during polar winter, has shown that absorbed $\mathrm{HO}_{2} \mathrm{NO}_{2}$ can be emitted into the atmosphere above the snowpack when temperatures increase (Jones et al., 
2014). $\mathrm{HO}_{2} \mathrm{NO}_{2}$ was also investigated as a possible source of $\mathrm{NO}_{y}$ during the Tropospheric Ozone Production about the Spring Equinox (TOPSE) campaign Stroud et al. (2003). Modelled $\mathrm{HO}_{2} \mathrm{NO}_{2}$ during February was comparable to the observed $\mathrm{NO}_{y}$ deficit of $60 \mathrm{pmol} \mathrm{mol}^{-1}$ between 3 and $6 \mathrm{~km}$; however, the authors also note that the modelled $\mathrm{HO}_{2} \mathrm{NO}_{2}$ increased during May, whilst the observed $\mathrm{NO}_{y}$ deficit had decreased. It is apparent that further measurements are required to determine both the species and sources of this odd $\mathrm{NO}_{y}$ observed at Summit during winter.

In summary, the seasonal and diurnal cycles of $\mathrm{NO}_{x}$ and $\mathrm{NO}_{y}$ at Summit show that PAN is the dominant $\mathrm{NO}_{y}$ species in this region year-round; however, $\mathrm{NO}_{x}$ is an important contributor to the $\mathrm{NO}_{y}$ budget in summer. Local thermal decomposition of PAN is unlikely at Summit, due to the cold temperatures; therefore, the $\mathrm{NO}_{x}$ observed during summer is likely to be the result of upward emissions from the snowpack. Long-range transport may also play a role, as Summit is also influenced by pollution plumes that are mixed into the boundary layer (discussed further in Sect. 3.2). During spring and summer the $\mathrm{NO}_{y}$ observed at Summit can be attributed primarily to $\mathrm{PAN}, \mathrm{NO}_{x}, \mathrm{HONO}$, and $\mathrm{HNO}_{3}$. Over winter, PAN is the dominant $\mathrm{NO}_{y}$ species, and alkyl nitrates are also likely to contribute to the observed $\mathrm{NO}_{y}$; however, there is still a large fraction of $\mathrm{NO}_{y}$ that is unaccounted for over winter, and requires further investigation.

\subsubsection{Non-methane hydrocarbons}

Figure 5 shows the results for the $\mathrm{C}_{2}-\mathrm{C}_{5}$ alkane NMHC measured during 2008-2010 at Summit in ambient air. Measurements of primarily firn air conducted with this system were presented by Helmig et al. (2014). NMHC show a strong seasonal cycle with maximum mole fractions during the winter and early spring period and a rapid decline towards the summer, due to an increase in photochemical processing. The monthly averages for the $\mathrm{C}_{2}-\mathrm{C}_{5}$ NMHC are given in Table 2 . During the summer period, measured mole fractions of the heavier NMHC were below or close to the detection limit. As expected, the phase of each NMHC is shifted due to the rate of reaction with $\mathrm{OH}$. The lightest of the NMHC shown in Fig. 5a, ethane $\left(\mathrm{C}_{2} \mathrm{H}_{6}\right)$, peaks in March with a monthly mean of $2100 \pm 151 \mathrm{pmol} \mathrm{mol}^{-1}$ (mean $\pm 1 \sigma$ ) in 2009, and $1835 \pm 174 \mathrm{pmol} \mathrm{mol}^{-1}$ in 2010 , and declines to a minimum of $\sim 600 \mathrm{pmol} \mathrm{mol}^{-1}$ in July/August. Heavier NMHC have lower mole fractions, peak earlier in the year, and reach a minimum earlier in summer due to their faster rate of reaction with $\mathrm{OH}$.

A comparison between the two winters shows monthly mean NMHC levels were consistently higher from November 2008 to March 2009 when compared to November 2009 to March 2010. However, the standard deviation values during the second winter are typically higher, suggesting greater variability in the NMHC levels in 2009-2010. The nonaveraged NMHC data (Fig. S6, Supplement), show there is

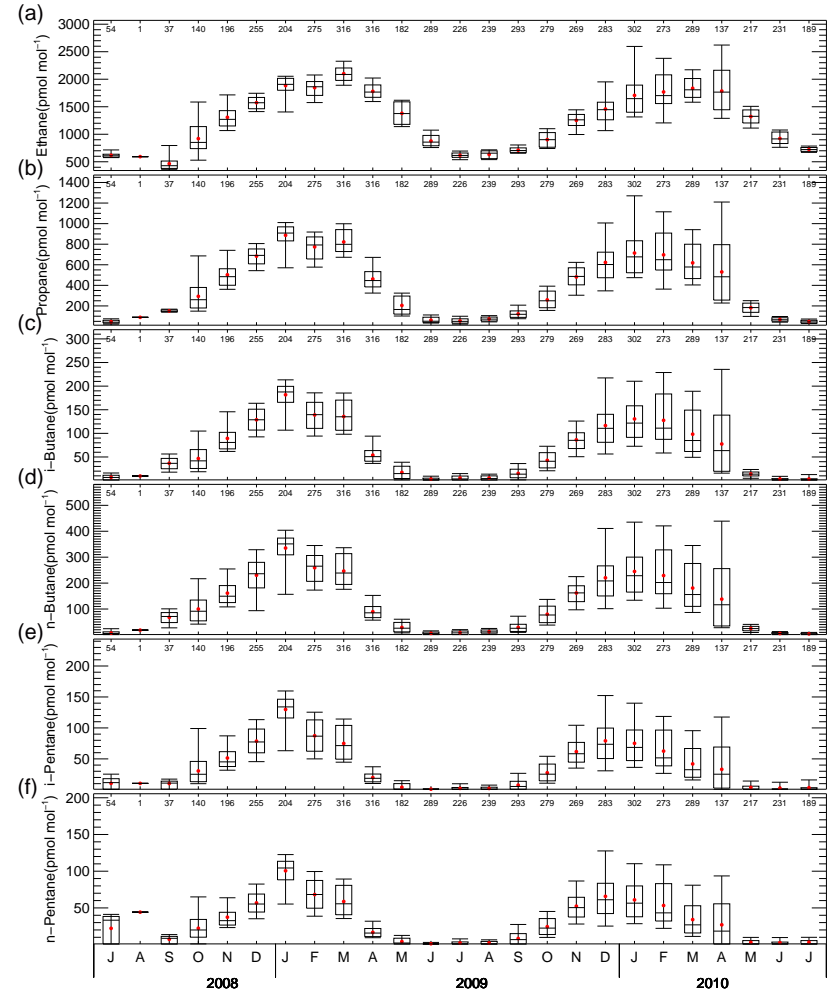

Figure 5. Monthly averages of (a) ethane, (b) propane, (c), $i$-butane, (d) $n$-butane, (e) $i$-pentane, and (f) $n$-pentane, at Summit during from July 2008 to July 2010. Median and mean are indicated by a horizontal line and black square, respectively; the box indicates the middle $67 \%$ of the data; and the vertical whiskers indicate the 5 th and 95th percentile of all the data. The numbers at the top of each plot represent the number of measurements included in the distribution.

considerable short-term variability in the NMHC mole fractions superimposed on the seasonal cycle, in particular during the winter months. Short-term elevated NMHC levels were observed during both winters and indicate fast transport of polluted air masses to the site.

The accumulation of $\mathrm{O}_{3}$ precursors, such as nitrogen oxides and NMHC over winter has been suggested as a potential in situ source of $\mathrm{O}_{3}$ that may contribute to the tropospheric $\mathrm{O}_{3}$ peak (e.g. Penkett et al., 1993; Honrath et al., 1996; Monks, 2000; Blake et al., 2003). Results from studies during the TOPSE Atlas et al. (2003), have shown that the photochemical production of $\mathrm{O}_{3}$ is important in the Arctic troposphere and can contribute more to the springtime $\mathrm{O}_{3}$ budget than $\mathrm{O}_{3}$ influx from stratosphere-troposphere exchange (Browell et al., 2003; Emmons et al., 2003).

The seasonality of NMHC can provide some insight into the potential for the photochemical production of $\mathrm{O}_{3}$ in the Arctic troposphere during spring. Measurements of NMHC and $\mathrm{O}_{3}$ during TOPSE show that within the mid-troposphere, total NMHC decreased by $\sim 6.2$ ppbC from February to May, and that $\mathrm{O}_{3}$ increased by $\sim 16 \mathrm{ppbv}$ during the same 
Table 2. Monthly statistics for NMHC measured at Summit from 2008 to 2010.

\begin{tabular}{|c|c|c|c|c|c|c|c|}
\hline Year & Month & $\begin{array}{c}\text { Ethane } \\
\left(\mathrm{pmol} \mathrm{mol}^{-1}\right) \\
\text { Mean } \pm \mathrm{SD}\end{array}$ & $\begin{array}{c}\text { Propane } \\
\left(\mathrm{pmol} \mathrm{mol}^{-1}\right) \\
\text { Mean } \pm \mathrm{SD}\end{array}$ & $\begin{array}{c}i \text {-Butane } \\
\left(\mathrm{pmolmol}^{-1}\right) \\
\text { Mean } \pm \mathrm{SD}\end{array}$ & $\begin{array}{c}n \text {-Butane } \\
\left(\mathrm{pmolmol}^{-1}\right) \\
\text { Mean } \pm \mathrm{SD}\end{array}$ & $\begin{array}{c}i \text {-Pentane } \\
\left(\mathrm{pmol} \mathrm{mol}^{-1}\right) \\
\text { Mean } \pm \mathrm{SD}\end{array}$ & $\begin{array}{c}n \text {-Pentane } \\
\left(\mathrm{pmol} \mathrm{mol}^{-1}\right) \\
\text { Mean } \pm \mathrm{SD}\end{array}$ \\
\hline \multirow[t]{6}{*}{2008} & Jul & $617 \pm 37$ & $46 \pm 18$ & $7 \pm 7$ & $8 \pm 7$ & $11 \pm 9$ & - \\
\hline & Aug & $593 \pm 0$ & $89 \pm 0$ & $10 \pm 0$ & $19 \pm 0$ & $10 \pm 0$ & - \\
\hline & Sep & $741 \pm 70$ & $151 \pm 9$ & $37 \pm 12$ & $68 \pm 21$ & $10 \pm 5$ & $8 \pm 5$ \\
\hline & Oct & $952 \pm 243$ & $293 \pm 146$ & $47 \pm 24$ & $100 \pm 49$ & $31 \pm 23$ & $22 \pm 15$ \\
\hline & Nov & $1308 \pm 194$ & $502 \pm 138$ & $89 \pm 35$ & $164 \pm 57$ & $51 \pm 24$ & $37 \pm 18$ \\
\hline & Dec & $1574 \pm 115$ & $684 \pm 85$ & $129 \pm 23$ & $243 \pm 49$ & $79 \pm 21$ & $57 \pm 13$ \\
\hline \multirow[t]{12}{*}{2009} & Jan & $1884 \pm 169$ & $887 \pm 118$ & $182 \pm 30$ & $343 \pm 52$ & $130 \pm 27$ & $100 \pm 19$ \\
\hline & Feb & $1846 \pm 147$ & $774 \pm 107$ & $139 \pm 28$ & $259 \pm 51$ & $87 \pm 24$ & $68 \pm 19$ \\
\hline & Mar & $2100 \pm 151$ & $822 \pm 116$ & $136 \pm 29$ & $246 \pm 56$ & $75 \pm 25$ & $59 \pm 18$ \\
\hline & Apr & $1779 \pm 121$ & $462 \pm 91$ & $54 \pm 15$ & $90 \pm 27$ & $20 \pm 8$ & $17 \pm 7$ \\
\hline & May & $1380 \pm 187$ & $205 \pm 84$ & $17 \pm 13$ & $29 \pm 18$ & $5 \pm 4$ & $5 \pm 4$ \\
\hline & Jun & $877 \pm 98$ & $61 \pm 27$ & $3 \pm 3$ & $6 \pm 5$ & $2 \pm 1$ & $2 \pm 1$ \\
\hline & Jul & $617 \pm 47$ & $54 \pm 22$ & $6 \pm 5$ & $9 \pm 6$ & $3 \pm 3$ & $3 \pm 2$ \\
\hline & Aug & $633 \pm 65$ & $73 \pm 19$ & $6 \pm 4$ & $13 \pm 7$ & $3 \pm 2$ & $3 \pm 2$ \\
\hline & Sep & $710 \pm 44$ & $122 \pm 36$ & $15 \pm 10$ & $29 \pm 18$ & $8 \pm 8$ & $9 \pm 7$ \\
\hline & Oct & $902 \pm 113$ & $259 \pm 75$ & $43 \pm 16$ & $80 \pm 31$ & $28 \pm 13$ & $24 \pm 11$ \\
\hline & Nov & $1253 \pm 125$ & $482 \pm 87$ & $86 \pm 20$ & $162 \pm 36$ & $62 \pm 20$ & $52 \pm 17$ \\
\hline & Dec & $1459 \pm 238$ & $623 \pm 182$ & $116 \pm 45$ & $220 \pm 85$ & $79 \pm 35$ & $66 \pm 30$ \\
\hline \multirow[t]{7}{*}{2010} & Jan & $1707 \pm 340$ & $714 \pm 208$ & $131 \pm 45$ & $245 \pm 88$ & $75 \pm 33$ & $61 \pm 27$ \\
\hline & Feb & $1769 \pm 323$ & $697 \pm 209$ & $128 \pm 51$ & $229 \pm 93$ & $63 \pm 32$ & $53 \pm 27$ \\
\hline & Mar & $1835 \pm 174$ & $619 \pm 164$ & $98 \pm 43$ & $181 \pm 80$ & $42 \pm 25$ & $34 \pm 21$ \\
\hline & Apr & $1785 \pm 381$ & $530 \pm 276$ & $77 \pm 62$ & $138 \pm 119$ & $33 \pm 34$ & $27 \pm 28$ \\
\hline & May & $1321 \pm 113$ & $182 \pm 44$ & $14 \pm 5$ & $25 \pm 9$ & $4 \pm 6$ & $4 \pm 3$ \\
\hline & Jun & $923 \pm 98$ & $68 \pm 19$ & $4 \pm 5$ & $6 \pm 4$ & $4 \pm 8$ & $3 \pm 4$ \\
\hline & Jul & $723 \pm 36$ & $48 \pm 23$ & $4 \pm 4$ & $4 \pm 4$ & $4 \pm 6$ & $4 \pm 3$ \\
\hline
\end{tabular}

period (Blake et al., 2003). The data from this study show similar results for NMHC, with the sum of the $\mathrm{C}_{2}-\mathrm{C}_{6} \mathrm{NMHC}$ decreasing by $\sim 4.5 \mathrm{ppbC}$ from February to May. The magnitude of the $\mathrm{O}_{3}$ increase, at $\sim 8 \mathrm{ppbv}$, is smaller than observed during TOPSE; however, the photochemical processing of $\mathrm{NMHC}$ in spring may contribute to the spring time peak of $\mathrm{O}_{3}$ over Greenland.

\subsection{Variability in ozone and its precursors from anthropogenic and biomass burning emissions}

In Sect. 3.1, the seasonal cycles for $\mathrm{O}_{3}$ precursors at Summit were discussed. Short-term enhancements in $\mathrm{O}_{3}$ precursor levels indicated that the boundary layer over Summit was often impacted by polluted air masses from lower latitudes. In this section the interannual and short-term variability in the measured species at Summit, from 2008 to 2010, as a result of changes in transport pathways and the relative source contributions of pollutants from North America, Europe, and Asia are investigated.

Figure 6 shows the total monthly averaged FLEXPART tracer simulations for $\mathrm{BC}_{\text {anthro }}$ and $\mathrm{BC}_{\text {fire }}$ tracers for 2008 , 2009 , and 2010. The data show that anthropogenic pollution impacts started to increase in November, peaking over the dark winter period, and then decreased in late spring. The total $\mathrm{BC}_{\text {anthro }}$ tracer at Summit is dominated by emissions from North America, Europe, and Asia. Source contributions from each continent can vary month-to-month and year-to-year; however, European emissions were typically the largest contributor to the total monthly $\mathrm{BC}_{\mathrm{anthro}}$ during the winter period, when the polar front recedes northwards. During winter (NDJFM) 2008-2009, 56\% of the total $\mathrm{BC}_{\text {anthro }}$ originated from Europe, with $33 \%$ from North America, and $11 \%$ from Asia. The following winter (NDJFM 2009-2010), European emission were higher at $69 \%$, with North America and Asia contributing 19 and $11 \%$, respectively. A very small contribution $(\lesssim 1 \%)$ of the total anthropogenic tracer originated from other continents. Figure 6 shows that the contribution to the total $\mathrm{BC}_{\text {anthro }}$ from Asia is low year-round. Hirdman et al. (2010) investigated the contribution of pollutants from different sources to various Arctic surface sites from 2002 to 2007. The authors show that Summit is less sensitive to emissions from the surface in the Arctic region, than low elevation surface stations, and air masses transported to Summit from outside of Greenland are likely to originate from Europe and North America. 


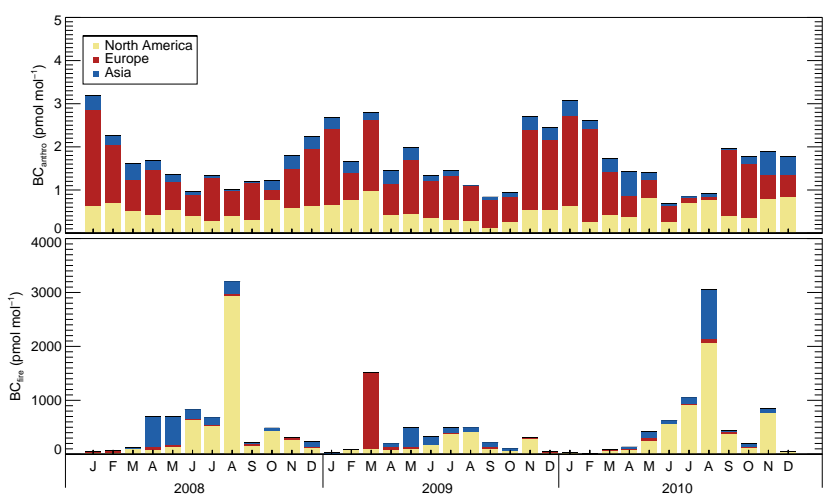

Figure 6. Bar chart showing the total monthly $\mathrm{BC}_{\text {anthro }}$ (top) and $\mathrm{BC}_{\text {fire }}$ (bottom) tracer from FLEXPART for 2008, 2009, and 2010. The different colours represent the contributions from North America, Europe, and Asia as shown in the legend.

In contrast to the anthropogenic tracer, North American emissions dominated the total $\mathrm{BC}_{\text {fire }}$ tracer, with $69 \%$ of the total $\mathrm{BC}_{\text {fire }}$ tracer originating from this region from July 2008 to July 2010. This result is expected as air masses arriving at Summit typically originate from North America during the summer months (Kahl et al., 1997). Previous studies have also shown that North America is a major source of biomass burning emissions transported to Summit (e.g. Whitlow et al., 1994; Legrand and de Angelis, 1996; Fuhrer and Legrand, 1997; Alexander et al., 2004; Stohl et al., 2006).

The high Asian contribution to the total $\mathrm{BC}_{\text {fire }}$ tracer in spring 2008 is in agreement with observations during the POLARCAT campaigns in 2008, when a number of biomass burning plumes were observed from Siberia (Law et al., 2014, and references therein). During the measurement period, however, the contribution from Asian biomass burning emissions at Summit was low, compared to North America. European biomass burning emissions were also low, except during a period in March, when European fires dominated the total $\mathrm{BC}_{\text {fire }}$ tracer. In 2008 and 2010 the contribution from total biomass burning emissions peaked in August. In 2009, however, there was no significant peak in biomass burning emissions at Summit, and $\mathrm{BC}_{\text {fire }}$ tracer levels during the summer were much lower overall.

Variability in $\mathrm{BC}_{\text {fire }}$ tracer can be a result of a change in emissions or transport pathways. Overpass and cloud-corrected MODIS Terra (MOD14CMH) and Aqua (MYD14CMH) fire pixel counts from the Climate Modelling Grid (CMG) product were downloaded from the University of Maryland ftp server (ftp://fuoco.geog.umd.edu) to investigate the variability in fire emissions. The monthly total fire pixel count and total fire radiative power (FRP), over the zonal region $40-75^{\circ} \mathrm{N}$, were determined from March to September for 2008, 2009, and 2010 separately. The results (Fig. S7a-d, Supplement) show that there was a reduction in total fire counts and FRP in summer 2009, when compared to 2008 and 2010.

In the next two sections, the impact of anthropogenic and biomass burning emissions on $\mathrm{O}_{3}$ and $\mathrm{O}_{3}$ precursors are investigated.

\subsubsection{Anthropogenic impacts}

To investigate the source of the observed variability and the impact on ozone precursor levels, the anthropogenic tracer from FLEXPART retroplume simulations $\left(\mathrm{BC}_{\text {anthro }}\right)$ and NMHC emissions ratios were used to determine changes in the transport pathways and relative source contributions of anthropogenic emissions from different continents.

An event with pollution transport was defined as identified when the $\mathrm{BC}_{\text {anthro }}$ tracer was greater than the 75 th percentile of the total $\mathrm{BC}_{\text {anthro }}$ during the 2 year measurement period (corresponding to $\mathrm{BC}_{\text {anthro }}>0.0082 \mathrm{pmol} \mathrm{mol}^{-1}$ ) for a minimum of $12 \mathrm{~h}$. The FLEXPART temporal resolution for backward simulations is $3 \mathrm{~h}$, so identifying events when the $\mathrm{BC}_{\text {anthro }}$ was enhanced for at least $12 \mathrm{~h}$ ensured that significant polluted air masses impacted the site. Using these thresholds, 85 anthropogenic pollution events were observed during the measurement period. Details for each event, including start date, FLEXPART tracer levels, and trace gas enhancements are presented in Table S2 in the Supplement. The mean weighted age of the plume was also calculated for each FLEXPART retroplume, to determine the typical transport time for the events. As shown in Fig. 6, anthropogenic impacts are observed year-round; however, during the summer anthropogenic pollution events can be mixed with biomass burning emissions. Therefore, for this study, the focus is on events between November and March when FLEXPART anthropogenic tracer levels peaked and biomass burning emissions were typically low. In total, 52 events were identified during the periods November to March 2008-2009 (events 12-37) and November to March 2009-2010 (events 55-80). Typical mean transport times for polluted air masses in winter were $\sim 11-12$ days.

During each event, the mean $\Delta \mathrm{PAN}, \Delta \mathrm{NO}_{y}, \Delta \mathrm{NO}_{x}, \Delta \mathrm{O}_{3}$, and $\Delta \mathrm{C}_{2} \mathrm{H}_{6}$ were calculated, where $\Delta$ is the enhancement above background levels (determined as the 20th percentile for each species, for each month and year). Care must be taken when defining a background level as the enhancement ratios are strongly dependent on this value. Initial analyses used a single background value for each month, determined from the 20th percentile of data from all years; however, this resulted in many negative or low enhancement ratios which were not consistent with the observations. A background value for each individual month and year was found to be more appropriate, as these levels change slightly from year to year. For the 52 anthropogenic events identified during winter, the median (and range) value of the enhancements were $38(-22$ to 295$) \mathrm{pmolmol}^{-1}$ for PAN, $6.6(-1.9$ to 88) $\mathrm{pmol} \mathrm{mol}^{-1}$ for $\mathrm{NO}_{x}, 67$ ( -17 to 334 ) $\mathrm{pmol} \mathrm{mol}^{-1}$ for 
$\mathrm{NO}_{y}, 1.2(-6.7$ to 7.6$) \mathrm{nmol} \mathrm{mol}^{-1}$ for $\mathrm{O}_{3}$, and $142(-245$ to 1119) $\mathrm{pmol} \mathrm{mol}^{-1}$ for $\mathrm{C}_{2} \mathrm{H}_{6}$.

Tests were performed to determine whether temporal mismatches occurred between the simulated plume arrivals and peaks in the measured species as a result of errors in the wind fields used in FLEXPART. Each event identified above was extended in time by $3,6,9$, and $12 \mathrm{~h}$ prior to and after the event, and new $\Delta$ values for the $\mathrm{O}_{3}$ precursors were calculated. The analyses showed that extending the event window did not have a large impact on the mean $\Delta$ values when mole fractions were low; i.e. levels were typically near the background already and extending the event time did not result in additional plumes being captured. During those events with large peaks in $\mathrm{O}_{3}$ and precursors, $\Delta$ values decreased, with increasing window lengths as a result of capturing lower background levels. Thus, the event times calculated using the original threshold appear to be in agreement with the pollution plume arrival times.

Over the two winters, negative mean $\Delta \mathrm{NO}_{y}$ values were observed during three events (event 72, 78, and 79), negative $\triangle \mathrm{PAN}$ during four events $(18,25,72$, and 73$)$ and negative $\Delta \mathrm{C}_{2} \mathrm{H}_{6}$ during four events $(64,72,73$, and 79). Negative $\Delta$ values were associated with (1) events when the

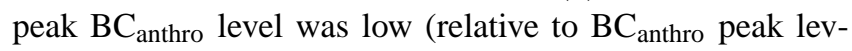
els during all events), indicating a small impact from anthropogenic pollution; (2) missing data points during the event; or (3) events when small enhancements in PAN and $\mathrm{NO}_{y}$ occurred; however, low mole fractions were also observed during the same event period.

Analyses of $\Delta \mathrm{O}_{3}$ and FLEXPART BC tracer masses show decreases in $\mathrm{O}_{3}\left(\Delta \mathrm{O}_{3}<0 \mathrm{nmol} \mathrm{mol}^{-1}\right)$, coinciding with anthropogenic pollution events, were observed during 20 periods in total from July 2008 to July 2010, with 16 of these events occurring between November and March, when sunlight is at a minimum. Negative $\Delta \mathrm{O}_{3}$ do not always coincide with low $\mathrm{O}_{3}$ precursor levels. For example, Fig. 7 shows a time series of measurements between 10 January and 2 March 2010. During this period, events with elevated ethane, $\mathrm{NO}_{y}, \mathrm{PAN}$, and $\mathrm{NO}_{x}$ levels are clearly correlated with enhancements in the FLEXPART BC tracer, suggesting polluted air masses impacting the site; however, what is particularly striking is that $\mathrm{O}_{3}$ mole fractions were low during some events (e.g. events 70, 71, and 74). Studies have shown that NMHC ratios can provide an indication of the photochemical aging of the air mass as the rate of reaction of different NMHC, and hence the ratio, is dependent on the amount of photochemical processing that occurs during transport (Parrish et al., 2004; Helmig et al., 2008; Honrath et al., 2008). High photochemical processing results in a decrease in the $\ln$ ([propane] / [ethane]) ratio as propane reacts more readily with $\mathrm{OH}$ than ethane. The two low ozone events, during this period, with the largest ethane enhancements (70 and 71) on 22 and 29 January, coincided with enhancements in the $\ln$ ([propane] / [ethane]) ratio, suggest-

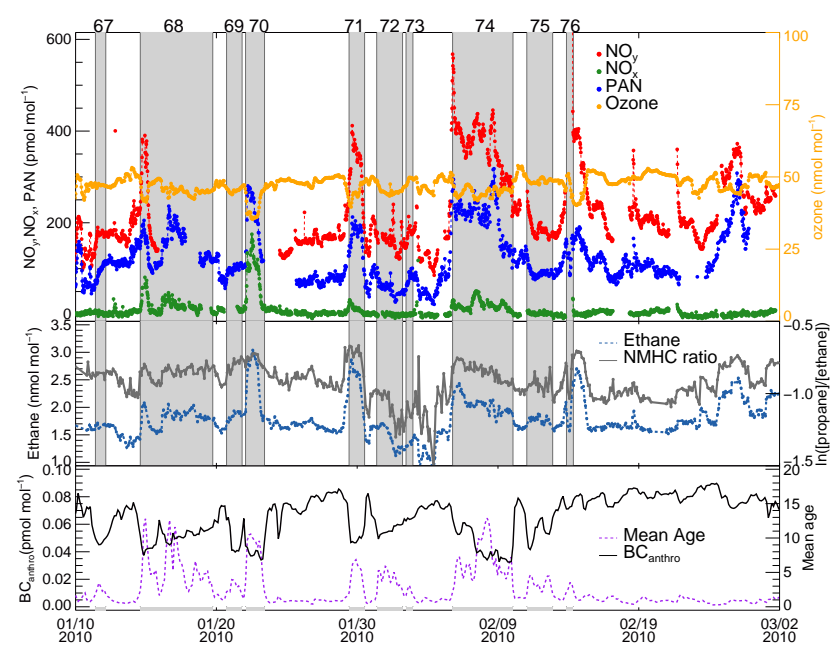

Figure 7. The top plot shows 30 min averages of $\mathrm{NO}_{x}, \mathrm{NO}_{y}$, PAN, and $1 \mathrm{~h}$ average of $\mathrm{O}_{3}$ from Summit between 10 January and 2 March 2010. The middle plot shows ethane mole fraction and $\ln ([$ propane] / [ethane]), and the bottom plot shows the FLEXPART $\mathrm{BC}_{\text {anthro }}$ tracer emissions (from all continents), and mean weighted age, for the same period. The shaded areas indicate the events discussed in detail in the main text and numbers at the top of the plot represent the event number (see Supplement for details on the events).

ing low photochemical processing, and fresher air masses; i.e. air that was subjected to more recent pollution before reaching at the site. It is difficult to obtain absolute air mass ages from NMHC ratios, due to dilution of the measured species during transport; however, the enhancements in the $\ln$ ([propane] / [ethane]) ratio during the two pollution events coincide with sudden decreases in the mean weighted age of the plumes, estimated from FLEXPART. The vertically integrated emission sensitivity (also called the total column sensitivity, measured in nanosecond metres per $\mathrm{kg}$ ) simulated by FLEXPART was used to determine the air mass transport pathway.

Figure 8a, shows the total column sensitivity from FLEXPART on 23 January (during event 70 ). The air mass originated from northern Europe and resided in the lower $\sim 2 \mathrm{~km}$ during transport, until 1 day upwind when the air mass ascended over the surface of the Greenland ice sheet to the measurement site. Mean $\triangle \mathrm{PAN}$ and $\Delta \mathrm{C}_{2} \mathrm{H}_{6}$ levels during this event were 125 and $1036 \mathrm{pmol} \mathrm{mol}^{-1}$, respectively, supporting the FLEXPART analyses indicating a polluted air mass was sampled (note there was no $\mathrm{NO}_{y}$ data available during this period). Note that $\mathrm{NO}_{x}$ was also enhanced (mean $\Delta \mathrm{NO}_{x}=87.7 \mathrm{pmol} \mathrm{mol}^{-1}$ ) during this event. As the air mass resided in the lower atmosphere before transport to the site, where temperatures are warmer, the enhanced $\mathrm{NO}_{x}$ observed is likely to be the result of PAN decomposition during transport. Ozone decreased, on average, $6.0 \mathrm{nmol} \mathrm{mol}^{-1}$ below the monthly background $\left(\mathrm{O}_{3(\mathrm{bkg})}=45 \mathrm{nmol} \mathrm{mol}^{-1}\right)$, and reached 
(a)

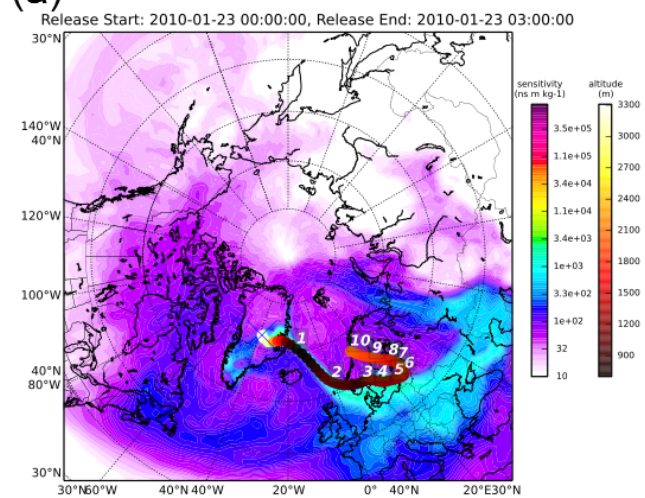

(b)

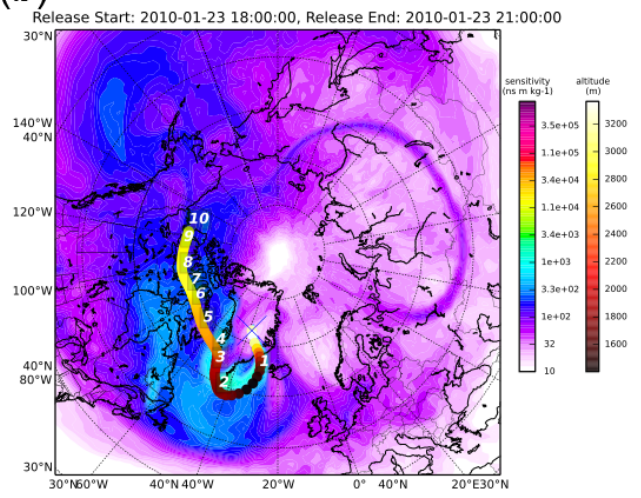

(c)

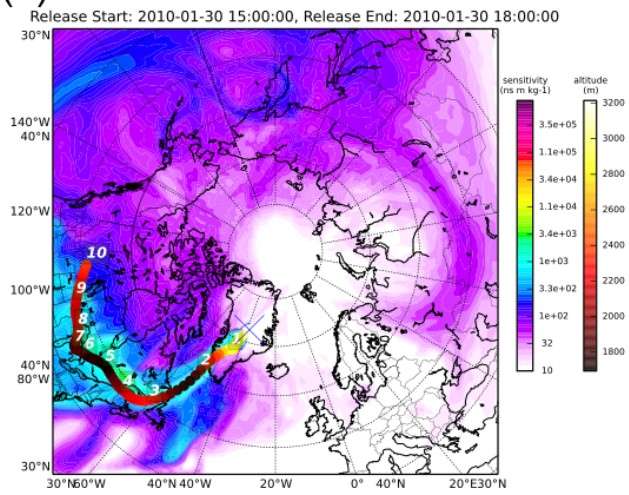

Figure 8. Simulated total column sensitivity $\left(\mathrm{ns} \mathrm{m} \mathrm{kg}^{-1}\right)$ for retroplumes originating at Summit on (a) 23 January 2010, at 00:00 UTC, (b) 23 January 2010, at 18:00 UTC, and (c) 30 January 2010, at 15:00 UTC. The altitude circles represent the centroid location of the particles in the model domain $\mathrm{N}$ days back from the measurement date, where $N$ is the number shown next to the shaded circles (up to 10 days are shown on the plots). The shading represents the altitude at three hourly intervals of the centroid location, given by the heat scale colourbar (note the change in scale for the colourbar).

a minimum level of $35.4 \mathrm{nmol} \mathrm{mol}^{-1}$. In contrast, a few hours later the transport patterns quickly changed, and the air masses sampled at Summit originated from high altitudes over North Canada, as shown in Fig. 8b. As a result, $\mathrm{O}_{3}$ levels increased and $\mathrm{NO}_{x}, \mathrm{PAN}$, and ethane all decreased. Air originating from the high Arctic region was sampled at the site until 29 January, when the air transport moved southward, and air masses residing in the lower troposphere over North America transported polluted air to Summit (Fig. 8c). From 29 to 30 January (event 71), ethane, $\mathrm{NO}_{y}, \mathrm{PAN}$, and $\mathrm{NO}_{x}$ all increased with mean enhancements of 1119, 184, 92.1, and $10.6 \mathrm{pmol} \mathrm{mol}^{-1}$, respectively. The mean $\Delta \mathrm{O}_{3}$ during event 71 was $-0.7 \mathrm{nmol} \mathrm{mol}^{-1}$, reaching a minimum $\mathrm{O}_{3}$ level of $39.6 \mathrm{pmol} \mathrm{mol}^{-1}$.

Background $\mathrm{O}_{3}$ levels at Summit are typically higher than those observed at lower elevation Arctic sites due to a stronger influence of transport from the stratosphere, a reduction in ozone depletion events from halogens, and low surface deposition rates (Helmig et al., 2007a, b; Hirdman et al., 2010). The decrease in $\mathrm{O}_{3}$ observed during winter/early spring is likely to be the result of titration of $\mathrm{O}_{3}$ by NO within the sampled air mass soon after emission (Eneroth et al., 2007; Hirdman et al., 2010) and reduced mixing with the background air. FLEXPART retroplume analyses indicate that low $\mathrm{O}_{3}$ events over winter typically coincide when sampling air masses originating from either Europe or North America, which have resided in the lower troposphere and/or are quickly transported over the Greenland ice sheet to the measurement site (examples of FLEXPART retroplumes are shown in Fig. S8a-e in the Supplement). In contrast, periods identified during winter as pollution events with positive $\mathrm{O}_{3}$ enhancement values often occurred when the air masses resided in the mid-troposphere during transport to the site (Fig. S9a-e), thus allowing for greater mixing with air from high tropospheric or stratospheric origin.

To investigate interannual variability in emissions and their impact on $\mathrm{O}_{3}$ and $\mathrm{O}_{3}$ precursors, a comparison of the enhancement values for $\Delta \mathrm{O}_{3}, \Delta \mathrm{PAN}$, and $\Delta \mathrm{C}_{2} \mathrm{H}_{6}$ was made over the two winters (no comparison was made for $\mathrm{NO}_{x}$ or $\mathrm{NO}_{y}$ as measurements were limited during winter 2008-2009). Results show that enhancements in $\mathrm{O}_{3}$ and $\mathrm{O}_{3}$ precursors during events were typically higher dur- 
ing the second winter season, with median (mean) values of 12 (37) $\mathrm{pmol} \mathrm{mol}^{-1}, 126$ (162) $\mathrm{pmol} \mathrm{mol}^{-1}$, and 0.7 (1.2) $\mathrm{nmol} \mathrm{mol}^{-1}$ in 2008-2009, and 51 (56) $\mathrm{pmol} \mathrm{mol}^{-1}$, 178 (237) $\mathrm{pmol} \mathrm{mol}^{-1}$, and 1.4 (1.3) $\mathrm{nmol} \mathrm{mol}^{-1}$ in 20092010 , for $\triangle \mathrm{PAN}, \Delta \mathrm{C}_{2} \mathrm{H}_{6}$, and $\Delta \mathrm{O}_{3}$, respectively. FLEXPART analyses, presented in Sect. 3.2, show that European emissions contributed a greater amount to the anthropogenic air masses arriving at Summit in winter 2009-2010 compared to the previous year; thus, the higher enhancements are consistent with expectation that European emissions have a larger impact on the Arctic lower atmosphere in winter than North America or Asia.

In this study, the impact from anthropogenic emissions, as identified through FLEXPART retroplume analyses, were the primary focus. However, enhancements in the measured species were also observed during periods which are not correlated with pollution events simulated by FLEXPART. For example, on 15 February and 24-28 February 2010, (Fig. 7), enhancements in PAN, $\mathrm{NO}_{y}$, and ethane are observed that do not coincide with high FLEXPART $\mathrm{BC}_{\text {anthro }}$ tracer levels. The $\mathrm{BC}_{\text {fire }}$ tracer from FLEXPART during this period is low, suggesting that the event was not the result of biomass burning emissions. The retroplume shows the air masses from these two events were transported over northern Canada and remained in the Arctic for many days before arriving at Summit (not shown here). It is unlikely that the air sampled was from stratospheric origin, as ethane levels were high and ozone decreased during these events. It is possible that there may be missing sources in FLEXPART, or that the pollution originated prior to the 20 day simulation.

Enhancements in $\mathrm{O}_{3}$ precursors that do not coincide with high FLEXPART tracer simulations were also observed during the spring months; however, $\mathrm{O}_{3}$ was typically enhanced during these events, suggesting a different source than those in February 2010. FLEXPART analyses indicate the air masses were well aged, therefore, mixing with air masses originating from the upper-troposphere and/or stratosphere is possible. For example, the highest PAN and $\mathrm{NO}_{y}$ levels during spring 2010 were observed between 22 and 24 April, when FLEXPART retroplumes show that the air masses were transported between 3300 and $4300 \mathrm{~m}$ a.s.1. (Fig. 9). During this same period, ethane and $\mathrm{O}_{3}$ were also high. This event may be an example of tropospheric air, with high levels of $\mathrm{NMHC}$, mixing with stratospheric air rich in $\mathrm{O}_{3}$ and $\mathrm{NO}_{y}$, resulting in PAN formation (Liang et al., 2011). The determination of the sources that result in enhancements in $\mathrm{O}_{3}$ and its precursors, that cannot be attributed to pollution transport, requires further investigation.

The study here has focused on anthropogenic impacts during the winter period as this is when FLEXPART anthropogenic tracers peak; however, it should be noted that high $\Delta \mathrm{O}_{3}$ events occurred in the summer months, in particular between May and August. Some of the anthropogenic air masses were mixed with BB plumes (as discussed in the next section); however, the largest enhancement in $\mathrm{O}_{3}$, dur-
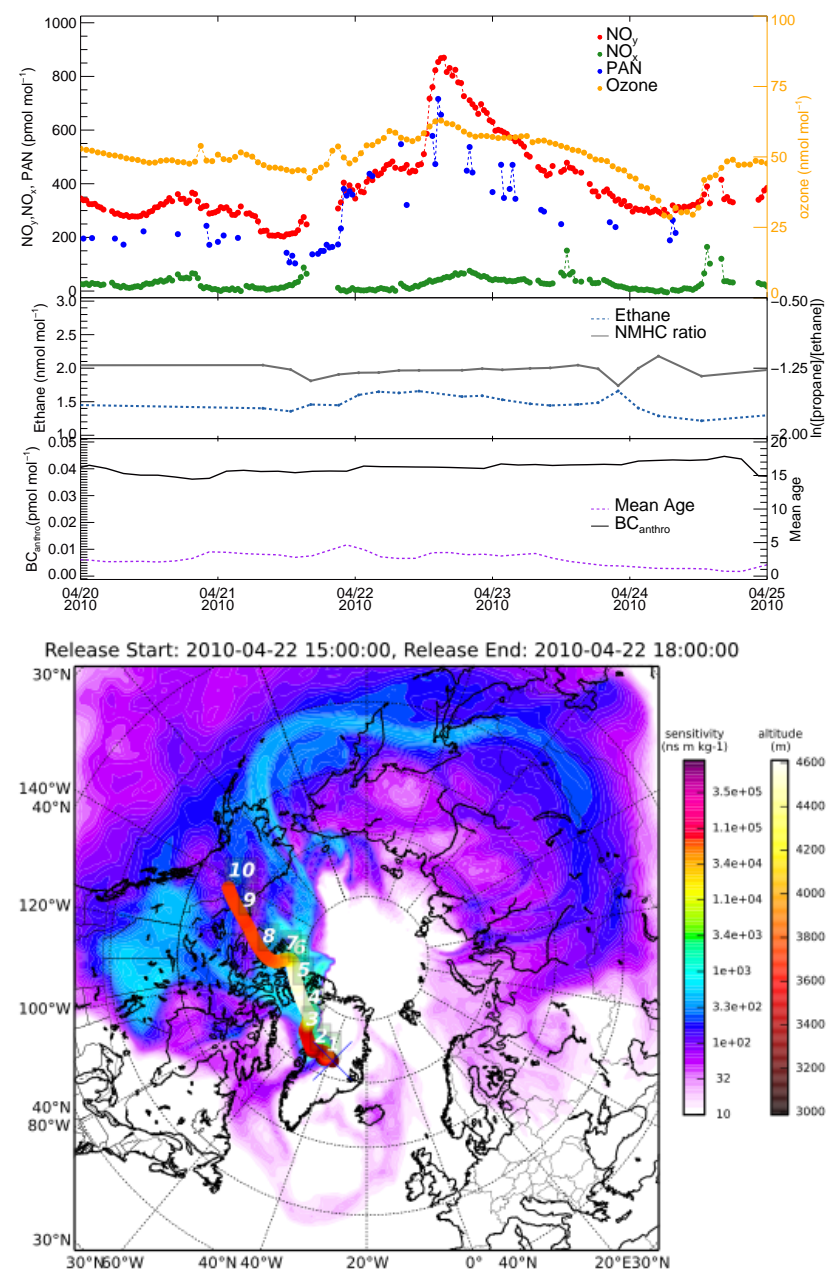

Figure 9. Top panel: $30 \mathrm{~min}$ averages of $\mathrm{NO}_{x}, \mathrm{NO}_{y}, \mathrm{PAN}, 1 \mathrm{~h}$ average of $\mathrm{O}_{3}, \mathrm{C}_{2} \mathrm{H}_{6}, \ln$ ([propane]/[ethane], and FLEXPART $\mathrm{BC}_{\text {fire }}$ tracer and mean weighted age at Summit from 20 to 25 April 2010. The vertical lines represent the arrival time of the FLEXPART simulated total column sensitivity at Summit on 22 April 2010, between 15:00 and 18:00 UTC, as shown in the bottom panel.

ing the measurement period $\left(\Delta \mathrm{O}_{3}=15.0 \mathrm{nmol} \mathrm{mol}^{-1}\right)$, occurred from 4 to 8 June 2009, as a result of transport of anthropogenic emissions from Europe to Summit in $\sim 10$ days. $\mathrm{O}_{3}$ precursors were also enhanced during this event, indicating that further $\mathrm{O}_{3}$ production may be possible during subsequent transport.

\subsubsection{Biomass burning impacts}

The extended whiskers shown on the plots in Fig. 1 indicate a large amount of variability in the $\mathrm{O}_{3}$ precursors during the summer months. Radiation, surface emissions, boundary layer height, and changes in air mass sampling may all contribute to the variability observed. Anthropogenic emission impacts tend to be lower in the summer as a result of reduced transport from source regions, as shown in Fig. 6; however, 
Table 3. Biomass burning events and mean enhancements in trace gases measured at Summit.

\begin{tabular}{|c|c|c|c|c|c|c|c|c|c|c|c|}
\hline Event & $\begin{array}{l}\text { Start } \\
\text { date }\end{array}$ & $\begin{array}{r}\text { Event } \\
\text { length } \\
\text { (h) }\end{array}$ & $\begin{array}{r}\mathrm{BC}_{\text {fire }} \\
\left(\mathrm{pmol} \mathrm{mol}^{-1}\right)\end{array}$ & $\begin{array}{r}\Delta \mathrm{O}_{3}{ }^{\mathrm{a}} \\
\left(\mathrm{nmol} \mathrm{mol}^{-1}\right)\end{array}$ & $\begin{array}{r}\Delta \text { PAN } \\
\left(\mathrm{pmol} \mathrm{mol}^{-1}\right)\end{array}$ & $\begin{array}{r}\Delta \mathrm{NO}_{x} \\
\left(\mathrm{pmol} \mathrm{mol}^{-1}\right)\end{array}$ & $\begin{array}{r}\Delta \mathrm{NO}_{y} \\
\left(\mathrm{pmol} \mathrm{mol}^{-1}\right)\end{array}$ & 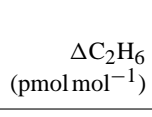 & $\begin{array}{r}\text { Plume age }{ }^{b} \\
\text { (days) }\end{array}$ & Source ${ }^{c}$ & $\mathrm{BC}_{\text {anthro }}^{\mathrm{d}}$ \\
\hline 1 & $25 \mathrm{Jul} 2008$ & 33 & 30.6 & -4.6 & 6.3 & 5.7 & 12.6 & 48.6 & 9 & NA & med \\
\hline 2 & 1 Aug 2008 & 15 & 25.0 & 7.0 & - & 1.8 & 20.9 & - & 15 & NA & low \\
\hline 3 & 3 Aug 2008 & 252 & 90.7 & 10.5 & 83.5 & 13.9 & 141 & - & 14 & NA & med \\
\hline 4 & 15 Mar 2009 & 60 & 58.6 & -0.5 & 2.1 & - & - & 107 & 12 & EU & med \\
\hline 5 & 18 Mar 2009 & 33 & 23.1 & 3.8 & -1.1 & - & - & -11.3 & 15 & EU & med \\
\hline 6 & 21 Mar 2009 & 21 & 17.6 & 3.8 & -20.9 & - & - & 11.6 & 16 & EU & low \\
\hline 7 & 27 May 2009 & 30 & 17.7 & 10.7 & 71.6 & - & - & - & 16 & AS & med \\
\hline 8 & 17 Jul 2009 & 12 & 19.9 & 4.6 & 67.2 & 6.2 & 108 & -9.6 & 13 & NA & low \\
\hline 9 & 18 Jul 2009 & 15 & 13.5 & 13.0 & 58.2 & 22.6 & 135 & 25.5 & 14 & NA & low \\
\hline 10 & 16 Aug 2009 & 18 & 11.8 & -4.1 & 3.3 & 16.0 & 11.8 & - & 18 & NA & low \\
\hline 11 & 18 Aug 2009 & 12 & 9.5 & 5.7 & 74.4 & 7.5 & 65.4 & 113 & 17 & NA & med \\
\hline 12 & 7 Jun 2010 & 27 & 11.3 & 8.9 & - & 5.6 & 105 & 13.1 & 13 & NA & high \\
\hline 13 & 18 Jul 2010 & 51 & 27.4 & 4.3 & - & 4.7 & 97.3 & 27.8 & 9 & NA & high \\
\hline
\end{tabular}

Europe, $\mathrm{AS}$ is Asia. ${ }^{\mathrm{d}}$ Indicates potential contribution from anthropogenic pollution. Low: $\mathrm{BC}_{\text {anthro }}<50$ th percentile, $, \mathrm{Med}_{\mathrm{B}} \mathrm{BC}_{\text {anthro }},<75$ th percentile, high: $\mathrm{BC}_{\text {anthro }},>75$ th percentile.

pollution from anthropogenic, and especially, BB emissions can still impact the centre of Greenland (Stohl, 2006), resulting in elevated mole fractions for short periods (Stohl et al., 2006). Studies based on aircraft measurements and models during the ARCTAS campaigns in both spring and summer 2008 show that $\mathrm{NO}_{x}, \mathrm{NO}_{y}, \mathrm{PAN}$, and hydrocarbons levels can be elevated in biomass and anthropogenic plumes transported to the Arctic (e.g. Alvarado et al., 2010; Singh et al., 2010; Hornbrook et al., 2011; Liang et al., 2011).

The $\mathrm{BC}_{\text {fire }}$ tracer from FLEXPART was used to identify periods at Summit that were potentially impacted by BB emissions. Potential inaccuracies with the FLEXPART simulation of transport pathways, fire identification, and tracer emission uncertainties may result in BB events being under or overestimated; however, FLEXPART has been successfully used to identify long-range transport of biomass burning emissions in many studies (e.g. Brioude et al., 2007; Stohl et al., 2007; Lapina et al., 2008; Quennehen et al., 2011, 2012; Schmale et al., 2011; Cristofanelli et al., 2013). Biomass burning events were characterized as having a FLEXPART $\mathrm{BC}_{\text {fire }}$ tracer $>90$ th percentile $\left(\simeq 7 \mathrm{pmol} \mathrm{mol}^{-1}\right)$. In total, 13 events were observed between July 2008 and July 2010 ranging in duration between 12 and $252 \mathrm{~h}$. Details regarding the start date, duration, mean plume age, FLEXPART tracer levels and trace gas levels for each event are shown in Table 3. A more conservative threshold was applied here than for the anthropogenic emissions in Sect. 3.2.1; consequently, the events identified had significant BB impacts but small anthropogenic signatures. Of these 13 events, two were identified as having potentially high anthropogenic signatures $\left(\mathrm{BC}_{\mathrm{anthro}}>75\right.$ th percentile) and were most likely plumes of mixed anthropogenic and biomass burning emissions, six events were identified as having medium anthropogenic signatures (75th percentile $>\mathrm{BC}_{\text {anthro }}>50$ th percentile) and the remaining five events were classified as having low anthropogenic signatures. The source contribution from FLEXPART shows that the majority of the BB events (9 out of 13) originated in North America, with the BB events originating in Europe all occurring in March 2009.

Analyses of $\mathrm{O}_{3}$ and its precursors at Summit show that the mean enhancements for PAN, $\mathrm{NO}_{x}, \mathrm{NO}_{y}$, and $\mathrm{C}_{2} \mathrm{H}_{6}$ during the BB events identified by FLEXPART are highly variable (Table 3). Values ranged between -4.6 and $13.0 \mathrm{nmol} \mathrm{mol}^{-1}$ for $\Delta \mathrm{O}_{3},-20.9$ to $83.5 \mathrm{pmol} \mathrm{mol}^{-1}$ for $\Delta \mathrm{PAN}, 1.8$ to $22.6 \mathrm{pmol} \mathrm{mol}^{-1}$ for $\Delta \mathrm{NO}_{x}, 11.8$ to $135 \mathrm{pmol} \mathrm{mol}^{-1}$ for $\Delta \mathrm{NO}_{y}$, and -11.3 to $113 \mathrm{pmol} \mathrm{mol}^{-1}$ for $\Delta \mathrm{C}_{2} \mathrm{H}_{6}$. Ethane levels were low during the summer in general, and there is a large gradient in NMHC with latitude (Blake et al., 2003); therefore, small or negative $\Delta \mathrm{C}_{2} \mathrm{H}_{6}$ values are expected at Summit, even with the transport of air masses from the south.

The range of $\mathrm{O}_{3}$ enhancements observed here are comparable to those by Thomas et al. (2013), who estimated ozone production of up to $3 \mathrm{nmol} \mathrm{mol}^{-1}$ in aged BB plumes in the mid- to upper-troposphere (peaking at $7 \mathrm{~km}$ ) over Greenland. Our results suggest that in the lower troposphere the enhancement may even be greater. The largest BB event identified by FLEXPART was observed in August 2008 (event 3), when the $\mathrm{BC}_{\text {fire }}$ tracer indicated $\mathrm{BB}$ plumes impacted the site continuously from 3 to 14 August, peaking at $\sim 91 \mathrm{pmol} \mathrm{mol}^{-1}$, as a result of large wildfires in Canada. We find $\mathrm{O}_{3}$ and its precursors were all positive during this period, with mean enhancements of 13.9 , and $141 \mathrm{pmolmol}^{-1}$ for $\Delta \mathrm{NO}_{x}$ and $\Delta \mathrm{NO}_{y}$ respectively. PAN data were not available during the main peak of the event; however, PAN from $6 \mathrm{Au}-$ gust onwards was elevated above background levels, with a mean $\triangle$ PAN value of $83.5 \mathrm{pmol} \mathrm{mol}^{-1}$. A closer analysis of the measurements in Fig. 10 shows that $\mathrm{O}_{3}$ was consistently high during the event with a mean enhancement of $10.5 \mathrm{nmol} \mathrm{mol}^{-1}$. The FLEXPART total column sensitivity shows that air masses were typically transported between 2500 and $3500 \mathrm{~m}$ a.s.l. to Summit. FLEXPART also indicates that anthropogenic pollution was present during this period; 

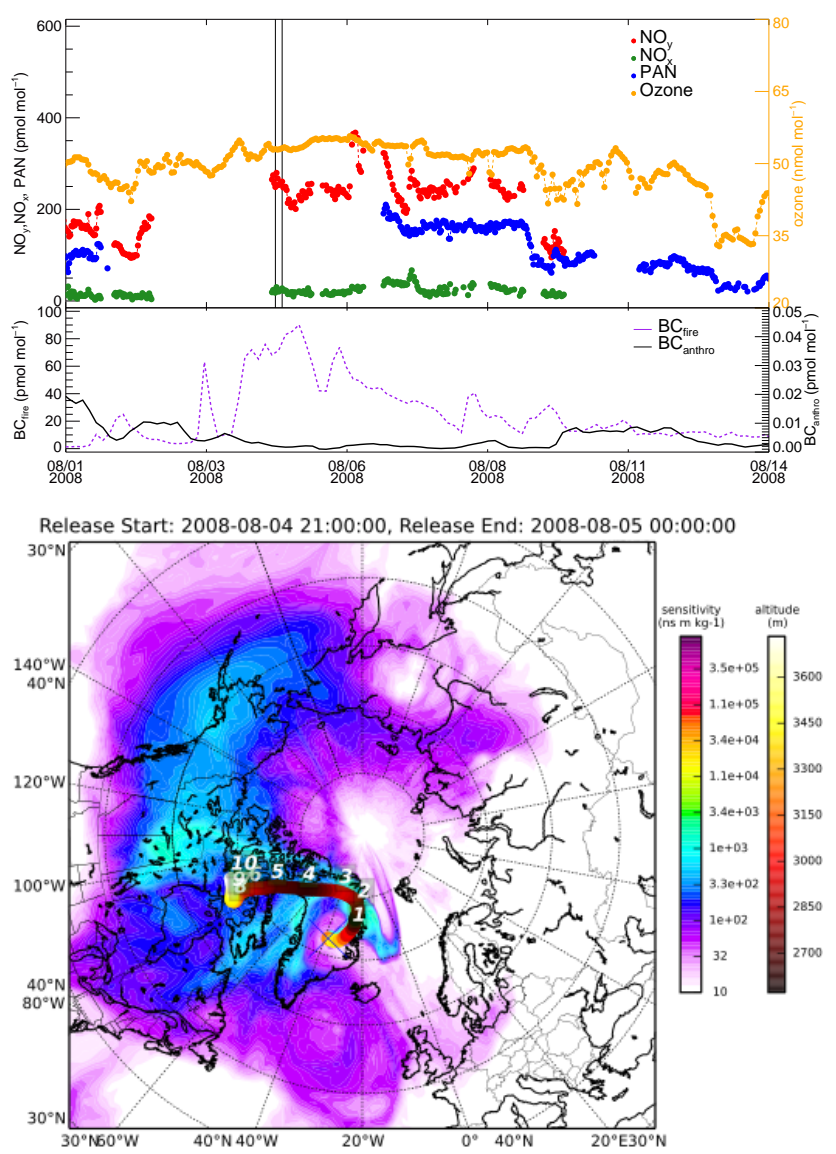

Figure 10. Top panel: $30 \mathrm{~min}$ averages of $\mathrm{NO}_{x}, \mathrm{NO}_{y}, \mathrm{PAN}$, and $1 \mathrm{~h}$ average of $\mathrm{O}_{3}$ and FLEXPART $\mathrm{BC}_{\text {fire }}$ and $\mathrm{BC}_{\text {anthro }}$ tracer at Summit from 1 to 14 August 2008. The vertical lines represent the arrival time of the FLEXPART simulated total column sensitivity at Summit between 4 August 2008, 21:00 UTC and 5 August 2008, 00:00 UTC, as shown in the bottom panel.

therefore, enhancements observed in the gas species may also be the result of anthropogenic pollution.

Enhanced PAN, $\mathrm{NO}_{x}$, and $\mathrm{NO}_{y}$ were observed during two BB events on July 17 and 18 July 2009 (event eight and nine). Plumes during both events were transported at lower altitudes ( 1950-2900 m) than the BB plume in August 2008, and had low anthropogenic signatures. Mean $\Delta \mathrm{O}_{3}$ levels were 4.6 and $13.0 \mathrm{nmol} \mathrm{mol}^{-1}$ during event numbers 8 and 9 , respectively, suggesting the $\mathrm{BB}$ emissions resulted in photochemical production of $\mathrm{O}_{3}$ during transport to the site. Care must be taken when interpreting these results. All the BB plumes sampled during this study have long transport times from source region to the measurement site, with mean weighted plume ages for the events ranging between 9 and 18 days (median 14 days). These aged plumes will be well mixed with background air; therefore, separating the pollution impacts from background levels is challenging.

Aged plumes transported at higher altitudes have a higher probability of mixing with high ozone from stratospheric ori- gin, which may contribute to the elevated $\mathrm{O}_{3}$ levels that were observed. For example, during event 7 , FLEXPART indicates that an aged plume (mean age $\sim 16$ days) originating from Asia, was transported over the North Pole between $\sim 3000$ and $4200 \mathrm{~m}$ a.s.l. A similar transport pattern was observed during the POLARCAT campaign, during which a plume, originating from Asia, was lifted within a warm conveyor belt over the North Pole towards Greenland (Roiger et al., 2011). The plume was then transported into the lower stratosphere, resulting in a well mixed tropospheric-stratospheric air mass with high $\mathrm{O}_{3}$ levels. The plume during event seven was transported at lower altitudes; however, mixing with air from stratospheric origin is not impossible and may be the cause of the $\mathrm{O}_{3}\left(\Delta \mathrm{O}_{3}=10.7 \mathrm{nmol} \mathrm{mol}^{-1}\right)$ and PAN $\left(\triangle \mathrm{PAN}=71.6 \mathrm{pmol} \mathrm{mol}^{-1}\right)$ levels observed.

$\mathrm{BB}$ plumes that are well mixed with background air can result in low precursor levels. In 2008 FLEXPART indicated that a BB event impacted the measurement site from 25 to 26 July (event 1 ). The total column sensitivity from the FLEXPART retroplume (see Fig. 11) shows that the air masses arriving at the site during this event originated from a region with $\mathrm{BB}$ sources over Canada and Alaska and were transported in the lower troposphere over the Arctic Ocean for $\sim 4$ days before ascending to Summit. The mean enhancement for $\mathrm{O}_{3}$ during this event was $-4.6 \mathrm{nmol} \mathrm{mol}^{-1}$ and $\mathrm{O}_{3}$ precursors have small enhancements. Similar results were observed in March 2009 (events 4, 5, 6), when $\triangle$ PAN values were low or negative and $\Delta \mathrm{O}_{3}$ levels were below $4 \mathrm{nmol} \mathrm{mol}{ }^{-1}$. During all three of these events, the air masses spent many days in the lower troposphere, over the Arctic ocean and the edge of the Greenland ice sheet, before ascending to Summit in 1-2 days. It is likely, during these events, the aged plumes were well mixed with marine air with low $\mathrm{O}_{3}$ and precursor mixing ratios.

\section{Summary}

These analyses of $\mathrm{NO}_{y}, \mathrm{NO}_{x}, \mathrm{PAN}, \mathrm{NMHC}$, and $\mathrm{O}_{3}$ from the high altitude GEOSummit station in Greenland show that PAN is the dominant species of $\mathrm{NO}_{y}$ at the site year-round, with monthly mean contributions ranging from a minimum of $42 \%$ in the summer months to $76 \%$ in spring. However, the $\mathrm{NO}_{y}$ seasonal cycle does not follow that of PAN, due to significant contributions from $\mathrm{NO}_{x}$ in the summer, and odd $\mathrm{NO}_{y}$ species during both summer and winter. We hypothesize that $\mathrm{HNO}_{3}, \mathrm{HONO}$, and alkyl nitrates are the largest sources of odd $\mathrm{NO}_{y}$ in the summer months. During the winter, mean monthly odd $\mathrm{NO}_{y}$ levels reach over $100 \mathrm{pmol} \mathrm{mol}^{-1}$. Approximately one-third of the odd $\mathrm{NO}_{y}$ is likely to be alkyl nitrates transported to the site. Previous studies have suggested that $\mathrm{HONO}, \mathrm{HNO}_{3}, \mathrm{NO}_{3}, \mathrm{~N}_{2} \mathrm{O}_{5}$, and $\mathrm{HO}_{2} \mathrm{NO}_{2}$ may also contribute to the wintertime $\mathrm{NO}_{y}$ levels.

Rapid changes in the origin of sampled air masses, from regions in Europe, North America, and the high lat- 

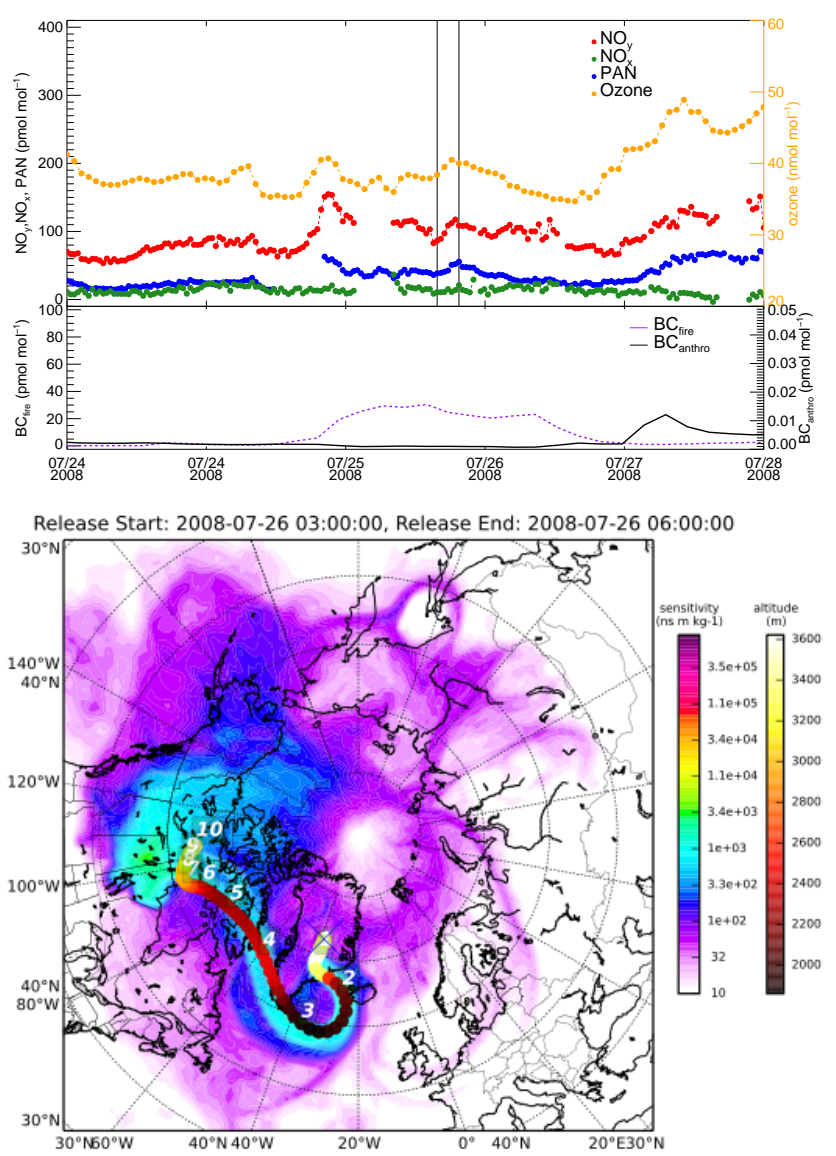

Figure 11. Top panel: $30 \mathrm{~min}$ averages of $\mathrm{NO}_{x}, \mathrm{NO}_{y}, \mathrm{PAN}$, and $1 \mathrm{~h}$ average of $\mathrm{O}_{3}$ and FLEXPART $\mathrm{BC}_{\text {fire }}$ and $\mathrm{BC}_{\text {anthro }}$ tracer at Summit from 24 to 27 July 2008. The vertical lines represent the arrival time of the FLEXPART simulated total column sensitivity at Summit on 26 July 2008, between 03:00 and 06:00 UTC, as shown in the bottom panel.

itude Arctic, result in a large variability in the measured species. Individual pollution events during November to March 2008-2009 and 2009-2010 show polluted air masses resulted in elevated ozone precursors above the background level with mean enhancements up to $334,295,88$, and $1119 \mathrm{pmol} \mathrm{mol}^{-1}$ for $\mathrm{NO}_{y}, \mathrm{PAN}, \mathrm{NO}_{x}$, and ethane, respectively. Enhancement values for PAN and ethane during the second winter were higher, possibly as a result of the increase in the contribution of air masses from Europe in 2009-2010 compared to 2008-2009. FLEXPART BC tracers and retroplume simulations indicate that European sources dominated the anthropogenic emissions impacting the site in November-March, contributing up to $56 \%$ of the anthropogenic BC tracer in 2009, and $69 \%$ in 2010. During the two winter seasons, 16 of the 52 events identified had negative mean $\Delta \mathrm{O}_{3}$ levels. These events often coincided with the arrival of polluted air masses that were transported quickly to the site, in only a few days, or transported within the lower troposphere. The reduced $\mathrm{O}_{3}$ within the plumes was likely due to the occurrence of $\mathrm{O}_{3}$ titration and reduced mixing with the higher background $\mathrm{O}_{3}$ at Summit. Enhanced $\mathrm{O}_{3}$ levels were also observed during the winter pollution events. These were typically associated with transport up to $\sim 3000$ $4000 \mathrm{~m}$ a.s.l., increasing the probability of mixing with $\mathrm{O}_{3}$ rich air from stratospheric origin.

FLEXPART tracer simulations indicated that biomass burning emissions transported to Summit during the summer in 2008-2010 primarily originated from North America. Biomass burning plumes from Europe were only present during a short period in March 2009. During 2009 measurements were performed over a full summer period; however, BB impacts were low in summer 2009, compared to 2008 and 2010. In total, 13 plumes were identified, and only five with low anthropogenic signatures. During the events, $\mathrm{O}_{3}$ and precursor levels were typically enhanced within the $\mathrm{BB}$ plumes with $\Delta \mathrm{O}_{3}$ levels up to $13.0 \mathrm{nmol} \mathrm{mol}^{-1}$ and $\Delta \mathrm{PAN}, \Delta \mathrm{NO}_{y}$, and $\Delta \mathrm{C}_{2} \mathrm{H}_{6}$ levels enhanced by up to $83.5,135 \mathrm{pmol} \mathrm{mol}^{-1}$, and $113 \mathrm{pmol} \mathrm{mol}^{-1}$, respectively. The results presented here show that BB plumes may potentially impact the $\mathrm{O}_{3}$ at Summit and the Arctic region in general; however, due to the long transport times and limited number of BB air masses transported to Summit during the measurement period, a quantitative analysis of the impact of $\mathrm{BB}$ plumes on $\mathrm{O}_{3}$ and $\mathrm{O}_{3}$ precursor levels is difficult. Future studies, with coincident $\mathrm{CO}, \mathrm{O}_{3}$, and $\mathrm{O}_{3}$ precursor measurements at Summit, would be valuable to determine enhancement ratios with respect to $\mathrm{CO}$ and evaluate the potential for ozone production in the region.

The data and results presented here show that the boundary layer at Summit is strongly impacted by both snowpack emissions and mixing of pollution plumes transported from North America and Europe. Anthropogenic emissions can impact the site year-round resulting in enhanced levels of $\mathrm{NO}_{y}$ in the boundary layer. Knowledge of pollution impacts over the Greenland ice sheet is important for modelling studies, in particular those that are focusing on snowpack-air exchange of gas species. Enhanced $\mathrm{NO}_{y}$ levels observed above the background during the events discussed here may have an important impact on snow photochemistry and the subsequent release of $\mathrm{NO}_{x}$ due to the uptake of $\mathrm{NO}_{y}$ species to the snowpack (Grannas et al., 2007, and references therein). Additionally, due to the stability of the Arctic free troposphere, the region is an effective reservoir for $\mathrm{O}_{3}$ precursors. The high $\mathrm{O}_{3}$ precursor mole fractions above background levels in spring and summer at Summit may have important implications for $\mathrm{NO}_{x}$ and $\mathrm{O}_{3}$ in the mid-latitudes during southerly flow of air masses (Hamlin and Honrath, 2002).

The Supplement related to this article is available online at doi:10.5194/acp-15-6827-2015-supplement. 
Acknowledgements. The authors acknowledge support for this project from the NASA ROSES program, grant number NNX07AR26G. A. Stohl was supported by the Norwegian Research Council in the framework of POLARCAT-Norway. Support for J. F. Burkhart was provided jointly under the Norwegian Research Council (project ES432275) and the US National Science Foundation (NSF1023651). The authors would like to acknowledge Mike Dziobak at Michigan Tech for all his valuable work with the instrumentation and Brie Van Dam and Jacques Heuber from The University of Colorado, Boulder, assisting with the measurements. We would like to thank the 109th Air National Guard and the support staff and science technicians from $\mathrm{CH} 2 \mathrm{M}$ Hill Polar Field Services for their valuable assistance and the Danish Commission for Scientific Research for providing access to GEOSummit station. The authors would also like to thank Jack Dibb and Meredith Hastings for sharing the $\mathrm{HNO}_{3}$ and $\mathrm{HONO}$ data from Summit.

Edited by: T. Bartels-Rausch

\section{References}

Alexander, B., Savarino, J., Kreutz, K. J., and Thiemens, M. H.: Impact of preindustrial biomass-burning emissions on the oxidation pathways of tropospheric sulfur and nitrogen, J. Geophys. Res., 109, D08303, doi:10.1029/2003JD004218, 2004.

Alvarado, M. J., Logan, J. A., Mao, J., Apel, E., Riemer, D., Blake, D., Cohen, R. C., Min, K.-E., Perring, A. E., Browne, E. C., Wooldridge, P. J., Diskin, G. S., Sachse, G. W., Fuelberg, H., Sessions, W. R., Harrigan, D. L., Huey, G., Liao, J., Case-Hanks, A., Jimenez, J. L., Cubison, M. J., Vay, S. A., Weinheimer, A. J., Knapp, D. J., Montzka, D. D., Flocke, F. M., Pollack, I. B., Wennberg, P. O., Kurten, A., Crounse, J., Clair, J. M. St., Wisthaler, A., Mikoviny, T., Yantosca, R. M., Carouge, C. C., and Le Sager, P.: Nitrogen oxides and PAN in plumes from boreal fires during ARCTAS-B and their impact on ozone: an integrated analysis of aircraft and satellite observations, Atmos. Chem. Phys., 10, 9739-9760, doi:10.5194/acp-10-9739-2010, 2010.

Anderson, P. S. and Neff, W. D.: Boundary layer physics over snow and ice, Atmos. Chem. Phys., 8, 3563-3582, doi:10.5194/acp-83563-2008, 2008.

Atlas, E. L., Ridley, B. A., and Cantrell, C.: The Tropospheric Ozone Production about the Spring Equinox (TOPSE) Experiment: Introduction, J. Geophys. Res., 108, 8353, doi:10.1029/2002JD003172, 2003.

Barrie, L. A. and Bottenheim, J. W.: Sulphur and nitrogen pollution in the Arctic atmosphere, in: Pollution of The Arctic Atmosphere, edited by: Sturges, W., Elsevier Press, New York, 155183, 1991.

Beine, H. J. and Krognes, T.: The seasonal cycle of peroxyacetyl nitrate (PAN) in the European Arctic, Atmos. Environ., 34, 933940, doi:10.1016/S1352-2310(99)00288-5, 2000.

Beine, H. J., Jaffe, D. A., and Herring, J. A.: High-latitude springtime photochemistry, Part I: $\mathrm{NO}_{x}$, PAN and Ozone Relationships, J. Atmos. Chem., 27, 127-153, 1997.

Beine, H. J., Honrath, R. E., Dominè, F., Simpson, W. R., and Fuentes, J. D.: $\mathrm{NO}_{x}$ during background and ozone depletion pe- riods at Alert: Fluxes above the snow surface, J. Geophys.Res., 107, 4584, doi:10.1029/2002JD002082, 2002.

Beine, H. J., Dominè, F., Ianniello, A., Nardino, M., Allegrini, I., Teinilä, K., and Hillamo, R.: Fluxes of nitrates between snow surfaces and the atmosphere in the European high Arctic, Atmos. Chem. Phys., 3, 335-346, doi:10.5194/acp-3-335-2003, 2003.

Bian, H., Colarco, P. R., Chin, M., Chen, G., Rodriguez, J. M., Liang, Q., Blake, D., Chu, D. A., da Silva, A., Darmenov, A. S., Diskin, G., Fuelberg, H. E., Huey, G., Kondo, Y., Nielsen, J. E., Pan, X., and Wisthaler, A.: Source attributions of pollution to the Western Arctic during the NASA ARCTAS field campaign, Atmos. Chem. Phys., 13, 4707-4721, doi:10.5194/acp-13-47072013, 2013.

Blake, N. J., Blake, D. R., Sive, B. C., Katzenstein, A., Meinardi, S., Wingenter, O. W., Atlas, E. L., Flocke, F., Ridley, B. A., and Sherwood Rowland, F.: The seasonal evolution of NMHCs and light alkyl nitrates at middle to high northern latitudes during TOPSE, J. Geophys. Res., 108, 8359, doi:10.1029/2001JD001467, 2003.

Bollinger, M. J., Sievers, R. E., Fahey, D. W., and Fehsenfeld, F. C.: Conversion of nitrogen dioxide, nitric acid, and $n$-propyl nitrate to nitroc oxide by gold-catalzed reduction with carbon monoxide, Anal. Chem., 55, 1980-1986, 1983.

Bottenheim, J. W., Sirois, A., Brice, K. A., and Gallant, A. J.: Five years of continuous observations of PAN and ozone, J. Geophys. Res., 99, 5333-5352, 1994.

Brioude, J., Cooper, O. R., Trainer, M., Ryerson, T. B., Holloway, J. S., Baynard, T., Peischl, J., Warneke, C., Neuman, J. A., De Gouw, J., Stohl, A., Eckhardt, S., Frost, G. J., McKeen, S. A., Hsie, E.-Y., Fehsenfeld, F. C., and Nédélec, P.: Mixing between a stratospheric intrusion and a biomass burning plume, Atmos. Chem. Phys., 7, 4229-4235, doi:10.5194/acp-7-4229-2007, 2007.

Browell, E. V., Hair, J. W., and Butler, C. F.: Ozone, aerosol, potential vorticity, and trace gas trends observed at high-latitudes over North America from February to May 2000, J. Geophys. Res., 108, 1-16, doi:10.1029/2001JD001390, 2003.

Chen, G., Davis, D., Crawford, J., Hutterli, L. M., Huey, L. G., Slusher, D., Mauldin, L., Eisele, F., Tanner, D., Dibb, J., Buhr, M., McConnell, J., Lefer, B., Shetter, R., Blake, D., Song, C. H., Lombardi, K., and Arnoldy, J.: A reassessment of $\left\{\mathrm{HO}_{x}\right\}$ South Pole chemistry based on observations recorded during ISCAT 2000, Atmos. Environ., 38, 5451-5461, 2004.

Chen, G. Huey, L. G., Crawford, J. H., Olson, J. R., Hutterli,M. A., Sjostedt, S., Tanner, D., Dibb, J., Lefer, B., Blake, N., Davis, D., and Stohl, A.: An assessment of the polar $\left\{\mathrm{HO}_{x}\right\}$ photochemical budget based on 2003 Summit Greenland field observations, Atmos. Environ., 36, 7806-7820, doi:10.1016/j.atmosenv.2007.06.014, 2007.

Cohen, L., Helmig, D., Neff, W., Grachev, A. A., and Fairall, C. W.: Boundary-layer dynamics and its influence on atmospheric chemistry at Summit, Greenland, Atmos. Environ., 41, 50445060, 2007.

Cristofanelli, P., Fierli, F., Marinoni, A., Calzolari, F., Duchi, R., Burkhart, J., Stohl, A., Maione, M., Arduini, J., and Bonasoni, P.: Influence of biomass burning and anthropogenic emissions on ozone, carbon monoxide and black carbon at the Mt. Cimone GAW-WMO global station (Italy, 2165 m a.s.1.), Atmos. Chem. Phys., 13, 15-30, doi:10.5194/acp-13-15-2013, 2013. 
Cullen, N. J. and Steffen, K.: Unstable near-surface boundary conditions in summer on top of the Greenland Ice Sheet, Geophys. Res., Lett., 28, 4491-4493, 2001.

Dassau, T. M., Shepson, P. B., Bottenheim, J. W., and Ford, K. M.: Peroxyacetyl nitrate photochemistry and interactions with the Arctic surface, J. Geophys. Res., 109, D18302, doi:10.1029/2004JD004562, 2004.

Dibb, J. E. and Fahnestock, M.: Snow accumulation, surface height change, and firn densification at Summit, Greenland: Insights from 2 years of in situ observation, J. Geophys. Res., 109, D24113, doi:10.1029/2003JD004300, 2004.

Dibb, J. E., Talbot, R. W., Robert, W., and Bergin, M. H.: Soluble acidic species in air and snow at Summit, Greenland, Geophys. Res. Lett., 21, 1627-1630, 1994.

Dibb, J. E., Talbot, R. W., Munger, J. W., Jacob, D. J., and Fan, S. M.: Air-snow exchange of $\mathrm{HNO}_{3}$ and $\mathrm{NO}_{y}$ at Summit, Greenland, J. Geophys. Res., 103, 3475-3486, 1998.

Dibb, J. E., Arsenault, M., Peterson, M. C., and Honrath, R. E.: Fast nitrogen oxide photochemistry in Summit, Greenland snow, Atmos. Environ., 36, 2501-2511, doi:10.1016/S13522310(02)00130-9, 2002.

Dibb, J. E., Albert, M., Anastasio, C., Atlas, E., Beyersdorf, A. J., Blake, N. J., Blake, D. R., Bocquet, F., Burkhart, J. F., Chen, G., Cohen, L., Conway, T. J., Courville, Z., Frey, M. M., Friel, D. K., Galbavy, E. S., Hall, S., Hastings, M. G., Helmig, D., Huey, L. G., Hutterli, M. A., Jarvis, J. C., Lefer, B. L., Meinardi, S., Neff, W., Oltmans, S. J., Rowland, F. S., Sjostedt, S. J., Steig, E. J., Swanson, A. L., and Tanner, D. J.: An overview of air-snow exchange at Summit, Greenland: Recent experiments and findings, Atmos. Environ., 41, 244995-245006, doi:10.1016/j.atmosenv.2006.12.006, 2007.

Dominé, F. and Shepson, P. B.: Air-snow interactions and atmospheric chemistry, Science, 297, 1506-1510, doi:10.1126/science.1074610, 2002.

Emmons, L. K., Hess, P., Klonecki, A., Tie, X., Horowitz, L., Lamarque, J.-F., Kinnison, D., Brasseur, G., Atlas, E., Browell, E., Cantrell, C., Eisele, F., Mauldin, R. L., Merrill, J., Ridley, B., and Shetter, R.: Budget of tropospheric ozone during TOPSE from two chemical transport models, J. Geophys. Res., 108, 8372, doi:10.1029/2002JD002665, 2003.

Eneroth, K., Holmén, K., Berg, T., Schmidbauer, N., and Solberg, S.: Springtime depletion of tropospheric ozone, gaseous elemental mercury and non-methane hydrocarbons in the European Arctic, and its relation to atmospheric transport, Atmos. Environ., 41, 8511-8526, doi:10.1016/j.atmosenv.2007.07.008, 2007.

Fahey, D. W., Eubank, C. S., Hubler, G., and Fehsenfeld, F. C.: Evaluation of a catalytic reduction technique for the measurement of total reactive odd-nitrogen $\mathrm{NO}_{y}$ in the atmosphere, Atmos. Chem., 3, 435-468, 1985.

Fisher, J. A., Jacob, D. J., Purdy, M. T., Kopacz, M., Le Sager, P., Carouge, C., Holmes, C. D., Yantosca, R. M., Batchelor, R. L., Strong, K., Diskin, G. S., Fuelberg, H. E., Holloway, J. S., Hyer, E. J., McMillan, W. W., Warner, J., Streets, D. G., Zhang, Q., Wang, Y., and $\mathrm{Wu}, \mathrm{S}$.: Source attribution and interannual variability of Arctic pollution in spring constrained by aircraft (ARCTAS, ARCPAC) and satellite (AIRS) observations of carbon monoxide, Atmos. Chem. Phys., 10, 977-996, doi:10.5194/acp10-977-2010, 2010.
Ford, K. M., Campbell, B. M., Bertman, S. B., Honrath, R. E., Peterson, M. C., and Dibb, J. E.: Studies of Peroxyacetyl nitrate (PAN) and its interaction with the snowpack at Summit, Greenland, J. Geophys. Res., 107, 1-10, 2002.

Fuhrer, K. and Legrand, M.: Continental biogenic species in the Greenland Ice Core Project ice core: Tracing back the biomass history of the North American continent, J. Geophys. Res., 102, 26735-26745, doi:10.1029/97JC01299, 1997.

Giglio, L., Descloitres, J., Justice, C. O., and Kaufman, Y.: An enhanced contextual fire detection algorithm for MODIS, Remote Sens. Environ., 87, 273-282, 2003.

Gilman, J. B., Burkhart, J. F., Lerner, B. M., Williams, E. J., Kuster, W. C., Goldan, P. D., Murphy, P. C., Warneke, C., Fowler, C., Montzka, S. A., Miller, B. R., Miller, L., Oltmans, S. J., Ryerson, T. B., Cooper, O. R., Stohl, A., and de Gouw, J. A.: Ozone variability and halogen oxidation within the Arctic and sub-Arctic springtime boundary layer, Atmos. Chem. Phys., 10, 10223-10236, doi:10.5194/acp-10-10223-2010, 2010.

Grannas, A. M., Jones, A. E., Dibb, J., Ammann, M., Anastasio, C., Beine, H. J., Bergin, M., Bottenheim, J., Boxe, C. S., Carver, G., Chen, G., Crawford, J. H., Dominé, F., Frey, M. M., Guzmán, M. I., Heard, D. E., Helmig, D., Hoffmann, M. R., Honrath, R. E., Huey, L. G., Hutterli, M., Jacobi, H. W., Klán, P., Lefer, B., McConnell, J., Plane, J., Sander, R., Savarino, J., Shepson, P. B., Simpson, W. R., Sodeau, J. R., von Glasow, R., Weller, R., Wolff, E. W., and Zhu, T.: An overview of snow photochemistry: evidence, mechanisms and impacts, Atmos. Chem. Phys., 7, 43294373, doi:10.5194/acp-7-4329-2007, 2007.

Hamlin, A. and Honrath, R.: A modeling study of the impact of winter-spring arctic outflow on the $\mathrm{NO}_{x}$ and $\mathrm{O}_{3}$ budgets of the North Atlantic troposphere, J. Geophys. Res., 107, 1-46, doi:10.1029/2001JD000453, 2002.

Helmig, D., Boulter, J., David, D., Birks, J. W., Cullen, N. J., Steffen, K., Johnson, B. J., and Oltmans, S. J.: Ozone and meteorological boundary-layer conditions at Summit, Greenland, during 3-21 June 2000, Atmos. Environ., 36, 2595-2608, 2002.

Helmig, D., Oltmans, S. J., Carlson, D., Lamarque, J.-F., Jones, A., Labuschagne, C., Anlauf, K., and Hayden, K.: A review of surface ozone in the polar regions, Atmos. Environ., 41, 5138-5161, doi:10.1016/j.atmosenv.2006.09.053, 2007a.

Helmig, D., Oltmans, S. J., Morse, T. O., and Dibb, J. E.: What is causing high ozone at Summit, Greenland?, Atmos. Environ., 41, 5031-5043, doi:10.1016/j.atmosenv.2006.05.084, 2007b.

Helmig, D., Tanner, D. M., Honrath, R. E., Owen, R. C., and Parrish, D. D.: Nonmethane hydrocarbons at Pico Mountain, Azores: 1. Oxidation chemistry in the North Atlantic region, J. Geophys. Res., 113, D20S91, doi:10.1029/2007JD008930, 2008.

Helmig, D., Stephens, C., Caramore, J., and Hueber, J.: Seasonal behavior of non-methane hydrocarbons in the firn air at Summit, Greenland, Atmos. Environ., 85, 234-246, doi:10.1016/j.atmosenv.2013.11.021, 2014.

Hirdman, D., Sodemann, H., Eckhardt, S., Burkhart, J. F., Jefferson, A., Mefford, T., Quinn, P. K., Sharma, S., Ström, J., and Stohl, A.: Source identification of short-lived air pollutants in the Arctic using statistical analysis of measurement data and particle dispersion model output, Atmos. Chem. Phys., 10, 669-693, doi:10.5194/acp-10-669-2010, 2010. 
Honrath, R. E. and Jaffe, D. A.: The seasonal cycle of nitrogen oxides in the Arctic troposphere at Barrow, Alaska, J. Geophys. Res., 97, 20615, doi:10.1029/92JD02081, 1992.

Honrath, R., Hamlin, A., and Merrill, J.: Transport of ozone precursors from the Arctic troposphere to the North Atlantic region, J. Geophys. Res., 101, 29335-29351, 1996.

Honrath, R., Peterson, M., Guo, S., Dibb, J. E., Shepson, P. B., and Campbell, B.: Evidence of $\mathrm{NO}_{x}$ production within or upon ice particles in the Greenland snowpack, Geophys. Res. Lett., 26, 695-698, 1999.

Honrath, R. E., Guo, S., and Peterson, M. C.: Photochemical production of gas phase $\mathrm{NO}$ from ice crystal $\mathrm{NO}_{3}^{-}$, J. Geophys. Res., 105, 24183-24190, 2000a.

Honrath, R. E., Peterson, M. C., Dziobak, M. P., Dibb, J. E., Arsenault, M. A., and Green, S. A.: Release of $\mathrm{NO}_{x}$ from sunlightirradiated midlatitude snow, Geophys. Res. Lett., 27, 2237-2240, doi:10.1029/1999GL011286, 2000b.

Honrath, R. E., Lu, Y., and Peterson, M. C.: Vertical fluxes of $\mathrm{NO}_{x}$, $\mathrm{HONO}$, and $\mathrm{HNO}_{3}$ above the snowpack at Summit, Greenland, Atmos. Environ., 36, 2629-2640, 2002.

Honrath, R. E., Helmig, D., Owen, R. C., Parrish, D. D., and Tanner, D. M.: Nonmethane hydrocarbons at Pico Mountain, Azores: 2. Event-specific analyses of the impacts of mixing and photochemistry on hydrocarbon ratios, J. Geophys. Res., 113, D20S92, doi:10.1029/2008JD009832, 2008.

Hornbrook, R. S., Blake, D. R., Diskin, G. S., Fried, A., Fuelberg, H. E., Meinardi, S., Mikoviny, T., Richter, D., Sachse, G. W., Vay, S. A., Walega, J., Weibring, P., Weinheimer, A. J., Wiedinmyer, C., Wisthaler, A., Hills, A., Riemer, D. D., and Apel, E. C.: Observations of nonmethane organic compounds during ARCTAS - Part 1: Biomass burning emissions and plume enhancements, Atmos. Chem. Phys., 11, 11103-11130, doi:10.5194/acp11-11103-2011, 2011.

Jobson, B., Wu, Z., Niki, H., and Barrie, L. A.: Seasonal trends of isoprene, $\mathrm{C}_{2}-\mathrm{C}_{5}$ alkanes, and acetylene at a remote boreal site in Canada, J. Geophys. Res., 99, 1589-1599, 1994.

Jones, A. E., Brough, N., Anderson, P. S., and Wolff, E. W.: $\mathrm{HO}_{2} \mathrm{NO}_{2}$ and $\mathrm{HNO}_{3}$ in the coastal Antarctic winter night: a "labin-the-field" experiment, Atmos. Chem. Phys., 14, 11843-11851, doi:10.5194/acp-14-11843-2014, 2014.

Justice, C. O., Giglio, L., Korontzi, S., Owens, J., Morisette, J. T., Roy, D., Descloitres, J., Alleaume, S., Petitcolin, F., and Kaufman, Y.: The MODIS fire products, Remote Sens. Environ., 83, 244-262, 2002.

Kahl, J. D. W., Martinez, D. A., Kuhns, H., Davidson, C. I., Jaffrezo, J. L., and Harris, J. M.: Air mass trajectories to Summit, Greenland: a 44-year climatology and some episodic events, J. Geophys. Res.-Oceans, 102, 26861-26875, doi:10.1029/97jc00296, 1997.

Karbiwnyk, C. M., Mills, C. S., Helmig, D., and Birks, J. W.: Use of chloroflurocarbons as internal standards for the measurement of atmospheric non-methane volatile organic compounds sampled onto solid adsorbent cartridges, Environ. Sci. Technol., 37, 10021007, 2003.

Kley, D. and Mcfarland, M.: Chemiluminescence detector for NO and $\mathrm{NO}_{2}$, Atmospheric Measurement Techniques, 12, 63-69, 1980.

Klonecki, A., Hess, P., Emmons, L., Smith, L., Orlando, J., and Blake, D.: Seasonal changes in the transport of pollutants into the Arctic troposphere-model study, J. Geophys. Res., 108, 8367 , doi:10.1029/2002JD002199, 2003.

Lamarque, J.-F. and Hess, P. G.: Model analysis of the temporal and geographical origin of the $\mathrm{CO}$ distribution during the TOPSE campaign, J. Geophys. Res., 108, 8369, doi:10.1029/2002JD002077, 2003.

Lapina, K., Honrath, R. E., Owen, R. C., Val Martín, M., Hyer, E. J., and Fialho, P.: Late summer changes in burning conditions in the boreal regions and their implications for $\mathrm{NO}_{x}$ and $\mathrm{CO}$ emissions from boreal fires, J. Geophys. Res., 113, D11304, doi:10.1029/2007JD009421, 2008.

Law, K. S. and Stohl, A.: Arctic air pollution: origins and impacts, Science, 315, 1537-1540, doi:10.1126/science.1137695, 2007.

Law, K. S., Stohl, A., Quinn, P. K., Brock, C., Burkhart, J., Paris, J.D., Ancellet, G., Singh, H. B., Roiger, A., Schlager, H., Dibb, J., Jacob, D. J., Arnold, S. R., Pelon, J., and Thomas, J. L.: Arctic Air Pollution: New Insights From POLARCAT-IPY, B. Am. Meteorol. Soc., 95, 1873-1895, doi:10.1175/BAMS-D-13-00017.1, 2014.

Legrand, M. and de Angelis, M.: Light carboxylic acids in Greenland ice: A record of past forest fires and vegetation emissions from the boreal zone, J. Geophys. Res., 101, 4129-4145, doi:10.1029/95JD03296, 1996.

Liang, Q., Rodriguez, J. M., Douglass, A. R., Crawford, J. H., Olson, J. R., Apel, E., Bian, H., Blake, D. R., Brune, W., Chin, M., Colarco, P. R., da Silva, A., Diskin, G. S., Duncan, B. N., Huey, L. G., Knapp, D. J., Montzka, D. D., Nielsen, J. E., Pawson, S., Riemer, D. D., Weinheimer, A. J., and Wisthaler, A.: Reactive nitrogen, ozone and ozone production in the Arctic troposphere and the impact of stratosphere-troposphere exchange, Atmos. Chem. Phys., 11, 13181-13199, doi:10.5194/acp-11-13181-2011, 2011.

Liao, J., Huey, L. G., Tanner, D. J., Brough, N., Brooks, S., Dibb, J. E., Stutz, J., Thomas, J. L., Lefer, B., Haman, C., and Gorham, K.: Observations of hydroxyl and peroxy radicals and the impact of BrO at Summit, Greenland in 2007 and 2008, Atmos. Chem. Phys., 11, 8577-8591, doi:10.5194/acp-11-8577-2011, 2011.

Liao, W., Case, A. T., Mastromarino, J., Tan, D., and Dibb, J. E.: Observations of HONO by laser-induced fluorescence at the South Pole during ANTCI 2003, Geophys. Res. Lett., 33, L09810, doi:10.1029/2005GL025470, 2006.

Monks, P. S.: A review of the observations and origins of the spring ozone maximum, Atmos. Environ., 34, 3545-3561, doi:10.1016/S1352-2310(00)00129-1, 2000.

Munger, J. W., Jacob, D. J., and Fan, S. M., Colman, A. S., and Dibb, J. E.: Concentrations and snow-atmosphere fluxes of reactive nitrogen at Summit, Greenland, J. Geophys. Res., 104, 13721-13734, 1999.

Muthuramu, K., Shepson, P. B., Bottenheim, J. W., Jobson, B. T., Niki, H., and Anlauf, K. G.: Relationships between organic nitrates and surface ozone destruction during Polar Sunrise Experiment 1992, J. Geophys. Res., 99, 13721-13734, 1994.

Parrish, D. D., Dunlea, E. J., Atlas, E. L., Schauffler, S., Donnelly, S., Stoud, V., Goldstein, A. H., Millet, D. B., McKay, M., Jaffe, D. A., Price, H. U., Hess, P. G., Flocke, F., and Roberts, J. M.: Changes in the photochemical environment of the temperate North Pacific troposphere in response to increased Asian emissions, J. Geophys. Res., 109, D23S18, doi:10.1029/2004JD004978, 2004. 
Penkett, S., Blake, N., Lightman, P., Marsh, A., Anwyl, P., and Butcher, G.: The seasonal variation of nonmethane hydrocarbons in the free troposphere over the North Atlantic Ocean: possible evidence for extensive reaction of hydrocarbons, J. Geophys. Res., 98, 2865-2885, 1993.

Peterson, M. C. and Honrath, R. E.: $\mathrm{NO}_{x}$ and $\mathrm{NO}_{y}$ over the northwestern North Atlantic: measurements and measurement accuray, J. Geophys. Res., 103, 13489-13503, 1999.

Petropavlovskikh, I. and Oltmans, S. J.: Tropospheric Ozone Measurements, 1973-2011, Version: 2012-07-10, NOAA, available at: ftp://aftp.cmdl.noaa.gov/data/ozwv/SurfaceOzone/ (last access: 24 March 2013), 2012.

Pollack, I. B., Lerner, B. M., and Ryerson, T. B.: Evaluation of ultraviolet light-emitting diodes for detection of atmospheric $\mathrm{NO}_{2}$ by photolysis - chemiluminescence, J. Atmos. Chem., 65, 111-125, doi:10.1007/s10874-011-9184-3, 2011.

Quennehen, B., Schwarzenboeck, A., Schmale, J., Schneider, J., Sodemann, H., Stohl, A., Ancellet, G., Crumeyrolle, S., and Law, K. S.: Physical and chemical properties of pollution aerosol particles transported from North America to Greenland as measured during the POLARCAT summer campaign, Atmos. Chem. Phys., 11, 10947-10963, doi:10.5194/acp-11-10947-2011, 2011.

Quennehen, B., Schwarzenboeck, A., Matsuki, A., Burkhart, J. F., Stohl, A., Ancellet, G., and Law, K. S.: Anthropogenic and forest fire pollution aerosol transported to the Arctic: observations from the POLARCAT-France spring campaign, Atmos. Chem. Phys., 12, 6437-6454, doi:10.5194/acp-12-6437-2012, 2012.

Quinn, P. K., Bates, T. S., Baum, E., Doubleday, N., Fiore, A. M., Flanner, M., Fridlind, A., Garrett, T. J., Koch, D., Menon, S., Shindell, D., Stohl, A., and Warren, S. G.: Short-lived pollutants in the Arctic: their climate impact and possible mitigation strategies, Atmos. Chem. Phys., 8, 1723-1735, doi:10.5194/acp8-1723-2008, 2008.

Ridley, B. A. and Grahek, F.: A small, low flow, high sensitivity reaction vessel for NO chemiluminescence detectors, Am. Meteorol. Soc., 7, 307-311, 1990.

Roiger, A., Aufmhoff, H., Stock, P., Arnold, F., and Schlager, H.: An aircraft-borne chemical ionization - ion trap mass spectrometer (CI-ITMS) for fast PAN and PPN measurements, Atmos. Meas. Tech., 4, 173-188, doi:10.5194/amt-4-173-2011, 2011.

Sander, S. P., Abbatt, J., Barker, J. R., Burkholder, J. B., Friedl, R. R., Golden, D. M., Huie, R. E., Kolb, C. E., Kurylo, M. J., Moortgat, G. K., Orkin, V. L., and Wine, P. H.: Chemical Kinetics and Photochemical Data for Use in Atmospheric Studies, Evaluation No. 17, JPL Publication 10-6, Jet Propulsion Laboratory, Pasadena, 2011, available at: http: //jpldataeval.jpl.nasa.gov (last access: 11 June 2015), 2013.

Schmale, J., Schneider, J., Ancellet, G., Quennehen, B., Stohl, A., Sodemann, H., Burkhart, J. F., Hamburger, T., Arnold, S. R., Schwarzenboeck, A., Borrmann, S., and Law, K. S.: Source identification and airborne chemical characterisation of aerosol pollution from long-range transport over Greenland during POLARCAT summer campaign 2008, Atmos. Chem. Phys., 11, 1009710123, doi:10.5194/acp-11-10097-2011, 2011.

Shindell, D.: Local and remote contributions to Arctic warming, Geophys. Res. Lett., 34, L14704, doi:10.1029/2007GL030221, 2007.

Shindell, D., Faluvegi, G., Lacis, A., Hansen, J., Ruedy, R., and Aguilar, E.: Role of tropospheric ozone increases in 20th-century climate change, J. Geophys. Res., 111, D08302, doi:10.1029/2005JD006348, 2006.

Shindell, D., Kuylenstierna, J. C. I., Vignati, E., van Dingenen, R., Amann, M., Klimont, Z., Anenberg, S. C., Muller, N., JanssensMaenhout, G., Raes, F., Schwartz, J., Faluvegi, G., Pozzoli, L., Kupiainen, K., Höglund-Isaksson, L., Emberson, L., Streets, D., Ramanathan, V., Hicks, K., Oanh, N. T. K., Milly, G., Williams, M., Demkine, V., and Fowler, D.: Simultaneously mitigating near-term climate change and improving human health and food security, Science, 335, 183-189, doi:10.1126/science.1210026, 2012.

Shindell, D. T., Chin, M., Dentener, F., Doherty, R. M., Faluvegi, G., Fiore, A. M., Hess, P., Koch, D. M., MacKenzie, I. A., Sanderson, M. G., Schultz, M. G., Schulz, M., Stevenson, D. S., Teich, H., Textor, C., Wild, O., Bergmann, D. J., Bey, I., Bian, H., Cuvelier, C., Duncan, B. N., Folberth, G., Horowitz, L. W., Jonson, J., Kaminski, J. W., Marmer, E., Park, R., Pringle, K. J., Schroeder, S., Szopa, S., Takemura, T., Zeng, G., Keating, T. J., and Zuber, A.: A multi-model assessment of pollution transport to the Arctic, Atmos. Chem. Phys., 8, 5353-5372, doi:10.5194/acp-85353-2008, 2008.

Singh, H., Anderson, B., Brune, W., Cai, C., Cohen, R., Crawford, J., Cubison, M., Czech, E., Emmons, L., and Fuelberg, H.: Pollution influences on atmospheric composition and chemistry at high northern latitudes: boreal and California forest fire emissions, Atmos. Environ., 44, 4553-4564, doi:10.1016/j.atmosenv.2010.08.026, 2010.

Solberg, S., Krognes, T., Stordal, F., Hov, Ø., Beine, H. J., Jaffe, D. A., Clemitshaw, K. C., and Penkett, S. A.: Reactive nitrogen compounds at Spitsbergen in the Norwegian Arctic, J. Atmos. Chem., 28, 209-225, 1997.

Stohl, A.: Characteristics of atmospheric transport into the Arctic troposphere, J. Geophys. Res., 111, D11306, doi:10.1029/2005JD006888, 2006.

Stohl, A., Forster, C., Eckhardt, S., Spichtinger, N., Huntrieser, H., Heland, J., Schlager, H., Wilhelm, S., Arnold, F., and Cooper, O.: A backward modeling study of intercontinental pollution transport using aircraft measurements, J. Geophys. Res., 108, 4370, doi:10.1029/2002JD002862, 2003.

Stohl, A., Forster, C., Frank, A., Seibert, P., and Wotawa, G.: Technical note: The Lagrangian particle dispersion model FLEXPART version 6.2, Atmos. Chem. Phys., 5, 2461-2474, doi:10.5194/acp-5-2461-2005, 2005.

Stohl, A., Andrews, E., Burkhart, J. F., Forster, C., Herber, A., Hoch, S. W., Kowal, D., Lunder, C., Mefford, T., Ogren, J. A., Sharma, S., Spichtinger, N., Stebel, K., Stone, R., Ström, J., Tørseth, K., Wehrli, C., and Yttri, K. E.: Pan-Arctic enhancements of light absorbing aerosol concentrations due to North American boreal forest fires during summer 2004, J. Geophys. Res., 111, D22214, doi:10.1029/2006JD007216, 2006.

Stohl, A., Berg, T., Burkhart, J. F., Fjae'raa, A. M., Forster, C., Herber, A., Hov, Ø., Lunder, C., McMillan, W. W., Oltmans, S., Shiobara, M., Simpson, D., Solberg, S., Stebel, K., Ström, J., Tørseth, K., Treffeisen, R., Virkkunen, K., and Yttri, K. E.: Arctic smoke - record high air pollution levels in the European Arctic due to agricultural fires in Eastern Europe in spring 2006, Atmos. Chem. Phys., 7, 511-534, doi:10.5194/acp-7-511-2007, 2007.

Stohl, A., Klimont, Z., Eckhardt, S., Kupiainen, K., Shevchenko, V. P., Kopeikin, V. M., and Novigatsky, A. N.: Black carbon in 
the Arctic: the underestimated role of gas flaring and residential combustion emissions, Atmos. Chem. Phys., 13, 8833-8855, doi:10.5194/acp-13-8833-2013, 2013.

Stroud, C., Madronich, S., Atlas, E., Ridley, B., Flocke, F., Weinheimer, A., Talbot, B., Fried, A., Wert, B., Shetter, R., Lefer, B., Coffey, M., Heikes, B., and Blake, D.: Photochemistry in the arctic free troposphere: $\mathrm{NO}_{x}$ budget and the role of odd nitrogen reservoir recycling, Atmos. Environ., 37, 3351-3364, doi:10.1016/S1352-2310(03)00353-4, 2003.

Swanson, A. L., Blake, N. J., Atlas, E., Flocke, F., Blake, D. R., and Sherwood Rowland, F.: Seasonal variations of $\mathrm{C}_{2}-\mathrm{C}_{4}$ nonmethane hydrocarbons and $\mathrm{C}_{1}-\mathrm{C}_{4}$ alkyl nitrates at the Summit research station in Greenland, J. Geophys. Res., 108, 4065, doi:10.1029/2001JD001445, 2003.

Tanner, D., Helmig, D., Hueber, J., and Goldan, P.: Gas chromatography system for the automated, unattended, and cryogenfree monitoring of $\mathrm{C}_{2}$ to $\mathrm{C}_{6}$ non-methane hydrocarbons in the remote troposphere, J. Chromatogr. A, 1111, 76-88, doi:10.1016/j.chroma.2006.01.100, 2006.

Thomas, J. L., Stutz, J., Lefer, B., Huey, L. G., Toyota, K., Dibb, J. E., and von Glasow, R.: Modeling chemistry in and above snow at Summit, Greenland - Part 1: Model description and results, Atmos. Chem. Phys., 11, 4899-4914, doi:10.5194/acp-11-48992011, 2011.

Thomas, J. L., Raut, J.-C., Law, K. S., Marelle, L., Ancellet, G., Ravetta, F., Fast, J. D., Pfister, G., Emmons, L. K., Diskin, G. S., Weinheimer, A., Roiger, A., and Schlager, H.: Pollution transport from North America to Greenland during summer 2008, Atmos. Chem. Phys., 13, 3825-3848, doi:10.5194/acp-13-38252013, 2013.

Ulrich, T., Ammann, M., Leutwyler, S., and Bartels-Rausch, T.: The adsorption of peroxynitric acid on ice between $230 \mathrm{~K}$ and $253 \mathrm{~K}$, Atmos. Chem. Phys., 12, 1833-1845, doi:10.5194/acp-12-18332012, 2012.

UNEP: Integrated Assessment of Black Carbon and Tropospheric Ozone, available at: http://www.unep.org/dewa/Portals/67/pdf/ BlackCarbon_report.pdf (last access: 11 June 2015), 2011.

Val Martín, M., Honrath, R. E., Owen, R. C., Pfister, G., Fialho, P., and Barata, F.: Significant enhancements of nitrogen oxides, black carbon, and ozone in the North Atlantic lower free troposphere resulting from North American boreal wildfires, J. Geophys. Res., 111, D23S60, doi:10.1029/2006JD007530, 2006.

Van Dam, B., Helmig, D., Neff, W., and Kramer, L.: Evaluation of Boundary Layer Depth Estimates at Summit Station, Greenland, J. Appl. Meteorol. Clim., 52, 2356-2362, 2013.

Villena, G., Bejan, I., Kurtenbach, R., Wiesen, P., and Kleffmann, J.: Interferences of commercial $\mathrm{NO}_{2}$ instruments in the urban atmosphere and in a smog chamber, Atmos. Meas. Tech., 5, 149-159, doi:10.5194/amt-5-149-2012, 2012.
Walker, T. W., Martin, R. V., van Donkelaar, A., Leaitch, W. R., MacDonald, A. M., Anlauf, K. G., Cohen, R. C., Bertram, T. H., Huey, L. G., Avery, M. A., Weinheimer, A. J., Flocke, F. M., Tarasick, D. W., Thompson, A. M., Streets, D. G., and Liu, X.: TransPacific transport of reactive nitrogen and ozone to Canada during spring, Atmos. Chem. Phys., 10, 8353-8372, doi:10.5194/acp10-8353-2010, 2010.

Walker, T. W., Jones, D. B. A., Parrington, M., Henze, D. K., Murray, L. T., Bottenheim, J. W., Anlauf, K., Worden, J. R., Bowman, K. W., Shim, C., Singh, K., Kopacz, M., Tarasick, D. W., Davies, J., von der Gathen, P., Thompson, A. M., and Carouge, C. C.: Impacts of midlatitude precursor emissions and local photochemistry on ozone abundances in the Arctic, J. Geophys. Res., 117, D01305, doi:10.1029/2011JD016370, 2012.

Weller, R., Minikin, A., König-Langlo, G., Schrems, O., Jones, A. E., Wolff, E. W., and Anderson, P. S.:Investigating possible causes of the observed diurnal variability in Antarctic $\mathrm{NO}_{y}$, Geophys. Res. Lett., 26, 2853-2856, doi:10.1029/1999GL900608, 1999.

Wespes, C., Emmons, L., Edwards, D. P., Hannigan, J., Hurtmans, D., Saunois, M., Coheur, P.-F., Clerbaux, C., Coffey, M. T., Batchelor, R. L., Lindenmaier, R., Strong, K., Weinheimer, A. J., Nowak, J. B., Ryerson, T. B., Crounse, J. D., and Wennberg, P. O.: Analysis of ozone and nitric acid in spring and summer Arctic pollution using aircraft, ground-based, satellite observations and MOZART-4 model: source attribution and partitioning, Atmos. Chem. Phys., 12, 237-259, doi:10.5194/acp-12-237-2012, 2012.

Whitlow, S., Mayewski, P. A., Dibb, J. E., Holdsworth, G., and Twickler, M.: An ice-core-based record of biomass burning in the Arctic and Subarctic, 1750-1980, Tellus B, 46, 234-242, doi:10.1034/j.1600-0889.1994.t01-2-00006.x, 1994.

Wofsy, S., Sachse, G., Gregory, G., Blake, D. R., Bradshaw, J. D., Sandholm, S. T., Singh, H., Barrick, J. A., Harriss, R. C., Talbot, R. W., Shipham, M. A., Browell, E. V., Jacob, D. J., and Logan, J. A.: Atmospheric chemistry in the Arctic and Subarctic: Influence of natural fires, industrial emissions, and stratospheric inputs, J. Geophys. Res., 97, 16731-16746, 1992.

Worthy, D., Trivett, N., Hopper, J. F., Bottenheim, J. W., and Levin, I.: Analysis of long range transport events at Alert, Northwest Territories, during the Polar Sunrise Experiment, J. Geophys. Res., 99, 25329-25344, 1994.

Yang, J., Honrath, R. E., Peterson, M. C., Dibb, J. E., Sumner, A. L., Shepson, P. B., Frey, M., Jacobi, H.-W., Swanson, A., and Blake, N.: Impacts of snowpack emissions on deduced levels of $\mathrm{OH}$ and peroxy radicals at Summit, Greenland, Atmos. Environ., 36, 2523-2534, 2002. 